\title{
A Inspeção do Trabalho no Brasil*
}

\author{
Adalberto Cardoso e Telma Lage
}

\section{INTRODUÇÃO}

\begin{abstract}
A avaliação do efeito das instituições trabalhistas sobre o funcionamento dos mercados de trabalho e da economia como um todo ganhou importância renovada nos últimos dez ou quinze anos na América Latina. Uma visão em particular tornou-se hegemônica entre nós, recomendando políticas invariavelmente favoráveis à flexibilização das leis trabalhistas, com o propósito de reativar o crescimento econômico, aumentar a produtividade das empresas e a competitividade dos países latino-americanos e, dessa maneira, facilitar sua adaptação
\end{abstract}

\footnotetext{
* Este trabalho resulta de projeto comparativo internacional coordenado por Graciela Bensusán (Universidad Autónoma Metropolitana - UAM, México) e financiado pelo Consejo Nacional de Ciencia y Tecnología - CONACYT e pelo Conselho Nacional de Desenvolvimento Científico e Tecnológico - CNPq. Além de Graciela Bensusán, agradecemos os comentários de Hector Palomino, Cecília Senén e Rodrigo Figueroa, os demais membros da equipe internacional, e de Michael Piore, Richard Locke, Maria Ester Feres, Mara Hernandez e Judith Tendler, além dos demais participantes de um seminário internacional sobre inspeção do trabalho organizado por Bensusán e Piore no Massachusetts Institute of Technology - MIT no início de 2005, quando versão preliminar deste estudo foi apresentada. Tal versão foi redigida quando Adalberto Cardoso realizava estágio pós-doutorado na Universidade de Warwick, Inglaterra, com bolsa da Coordenação de Aperfeiçoamento de Pessoal de Nível Superior - Capes. Por fim, agradecemos os comentários de dois pareceristas anônimos da Dados, que contribuíram decisivamente para a versão final do trabalho. Escusado dizer que é dos autores a responsabilidade pelos eventuais equívocos de argumentação.
}

DADOS - Revista de Ciências Sociais, Rio de Janeiro, Vol. 48, n-3, 2005, pp. 451 a 490. 
às exigências da globalização. No entanto, a experiência indica que os resultados alcançados através dessas políticas foram muito diversos e, em vários casos, distantes dos objetivos originalmente almejados ${ }^{1}$. Além disso, mudanças semelhantes tiveram, muitas vezes, efeitos distintos e provocaram resultados não antecipados, entre outras razões, por não considerarem a natureza complexa das instituições do mercado de trabalho. Por não considerarem, também, que essas instituições não podem ser analisadas de maneira isolada (descuidando de sua articulação interna, suas funções ambivalentes e os graus reais de cumprimento das leis trabalhistas), sendo o resultado da combinação de um conjunto de fatores históricos e culturais que não se transferem facilmente de um país para outro. Esses fatores quase nunca são considerados na hora de se recomendar políticas uniformes para distintos países.

Um dos aspectos negligenciados pela literatura a respeito dos efeitos da regulação trabalhista sobre a eficiência dos mercados de trabalho é o grau de efetividade da lei, isto é, sua vigência real no cotidiano das relações de trabalho ${ }^{3}$. Mesmo estudos econométricos mais sofisticados, que levam em conta efeitos de interação entre instituições reguladoras do mercado de trabalho na explicação de sua dinâmica - como os de Belot e Ours (2001; 2004), deixam de lado essa questão central que é a obediência ou não à lei. Por outras palavras, o sistema de regulação do trabalho de determinado país pode ser muito detalhado e rígido em termos formais, mas muito flexível na prática, simplesmente porque os empregadores podem escolher não cumprir o que a lei prescreve. Argumentamos que o Brasil é um desses casos.

Desde que a Organização Internacional do Trabalho - OIT editou, em 1947, sua Convenção 81, regulando a inspeção do trabalho em países de tradição de relações de trabalho reguladas por lei e não por contratos (como Brasil, Argentina e México, por exemplo), a probabilidade de ser pego e sancionado por descumprir a lei depende sobretudo do desenho dos sistemas nacionais de inspeção e vigilância do trabalho ${ }^{4}$. No caso brasileiro, esse sistema inclui três agentes principais: 1) o poder público, por meio do Ministério do Trabalho e Emprego - MTE, no exercício de seu poder fiscalizador; e do Ministério Público do Trabalho, no manejo das ações civis públicas para defesa de interesses coletivos; 2 ) os sindicatos de trabalhadores e entidades da sociedade civil;3) a Justiça do Trabalho, quando manda reparar lesão a direitos trabalhistas. 
O objetivo deste artigo é investigar a atividade do primeiro desses agentes, o poder público, avaliando a eficiência (em termos dos meios empregados na inspeção), a eficácia (tendo em vista os objetivos visados) e a efetividade (ou o grau de abrangência) da ação fiscal. A pergunta a ser respondida aqui é bastante direta: tendo em vista que a efetividade da legislação trabalhista depende, como veremos, do efeito de interação entre o montante das sanções e a probabilidade do empregador ser apanhado burlando a lei; e tendo em vista que a efetividade da lei é aspecto decisivo para a real mensuração dos custos trabalhistas de um país; em que medida o sistema de inspeção do trabalho no Brasil está desenhado para cumprir seu objetivo, que é o de fazer cumprir a lei? Para responder a esta pergunta, apresentamos, primeiro, a estrutura de oportunidades enfrentada por empresários diante da alternativa de cumprir ou não a lei. As sanções por não-cumprimento também são analisadas. Em seguida, construímos um breve histórico do sistema brasileiro de inspeção do trabalho. Na terceira seção, descrevemos o sistema em detalhe, mostrando a estrutura responsável pela inspeção, suas prerrogativas e poderes. A quarta seção trata dos resultados materiais do funcionamento do sistema, isto é, avalia-se sua eficácia, eficiência e efetividade. Na conclusão, resumimos os achados, mostrando que o sistema vem melhorando, mas que não cumpre inteiramente o objetivo maior que talvez lhe coubesse: reduzir a taxa de ilegalidade das relações de trabalho no país, aumentando o número de empresas e trabalhadores incluídos no mundo do trabalho regulado.

\section{CUSTOS DE CUMPRIR OU NÃO A LEI TRABALHISTA}

Do ponto de vista estrito da gestão de uma empresa, cumprir ou não a legislação trabalhista é uma decisão racional de custo-benefício do empreendedor individual. Se o empregador considerar que os custos trabalhistas são muito altos, ele pode decidir correr o risco de não pagá-los. Essa decisão leva em conta uma síndrome de condicionantes. $\mathrm{O}$ risco, obviamente, é uma função direta da probabilidade de ele ser apanhado burlando a lei e da sanção (ou os custos econômicos e por vezes pessoais) que lhe será aplicada por não-cumprimento. A estrutura (simplificada) de oportunidades pode ser apreendida pelo quadro abaixo. Na linha encontra-se o risco de o empregador ser apanhado burlando a lei e de ser efetivamente sancionado (risco alto ou baixo). 
Na coluna, o montante relativo (tendo em vista os custos de não se cumprir a lei) da pena que lhe será aplicada (também alto ou baixo).

\begin{tabular}{|c|c|c|c|}
\hline \multicolumn{4}{|c|}{ Quadro 1} \\
\hline & & \multicolumn{2}{|c|}{ Montante Relativo da Sanção } \\
\hline & & Alto & Baixo \\
\hline \multirow{2}{*}{$\begin{array}{l}\text { Risco de ser apanha- } \\
\text { do e sofrer sanção }\end{array}$} & Alto & 1. Cumprir & 3. Não Cumprir \\
\hline & Baixo & 2. Não Cumprir & 4. Não Cumprir \\
\hline
\end{tabular}

Da combinação dessas possibilidades temos quatro resultados típicos: 1) o empregador cumpre a lei, porque a sanção é considerada alta o suficiente para tornar racional evitá-la, e o risco de ser pego e punido é também alto o suficiente para ser crível (digamos, significativamente superior a 50\%); 2) o empregador não cumpre a lei porque, embora a sanção por não cumprir seja alta, a probabilidade de ser apanhado é muito baixa, por exemplo, significativamente inferior a $50 \%$; 3 ) se o risco de ser pego é alto, mas a sanção é considerada pequena o bastante para tornar racional sofrê-la em lugar de incorrer nos custos trabalhistas, a lei não será cumprida; 4) finalmente, se a sanção for baixa e o risco de ser pego também, a lei tampouco será cumprida.

Note-se que, nesse quadro, os custos trabalhistas estão pressupostos no montante relativo da sanção. Ainda do ponto de vista da gestão do negócio, a sanção é alta ou baixa por comparação com os custos monetários de se cumprir a lei. A estrutura de oportunidades descrita acima só faz sentido, pois, em uma situação em que os custos trabalhistas são considerados suficientemente altos tendo em vista a planilha de custos e lucros projetados da empresa, em uma situação de competição de mercado em que as outras empresas encaram a mesma estrutura de oportunidades.

Esse quadro esquemático é útil sobretudo por mostrar que a estratégia dominante é o não-cumprimento da legislação. Empresários racionais defrontados com custos do trabalho considerados suficientemente altos tenderão a não assumi-los a menos que as sanções sejam maiores do que esse custo e que a probabilidade de ser pego e sancionado seja suficientemente crível. Qualquer outra combinação de fatores será um incentivo ao não-cumprimento da lei. Logo, a variável decisiva aqui é $o$ 
efeito de interação entre o custo de não cumprir e a probabilidade de ser apanhado e punido. A literatura que trata da relação entre custos trabalhistas e dinâmica dos mercados de trabalho negligencia esse aspecto central para as estratégias empresariais que é a efetividade da lei, resultante de uma estrutura de oportunidades onde a probabilidade de ser pego por não cumpri-la é decisiva.

Mas quanto custa não cumprir a lei no Brasil? Entre nós, a rede de proteção legal ao trabalhador compõe-se de mecanismos diversos e complementares, que podem ser acionados em diferentes momentos da relação empregatícia. Assim, uma primeira instância de controle é estabelecida na relação empregador/empregado, considerado isoladamente. Neste caso, o empregado é o próprio "agente fiscalizador", que vai apontar a inadimplência do empregador (atraso, adiamento, ou sonegação de contraprestações que lhe são devidas). Exemplos dessa situação são o pagamento em dobro das férias não-concedidas no prazo assinalado; pagamento em dobro do trabalho em dia de repouso; aumento de $50 \%$ sobre o valor da hora normal, quando do trabalho em intervalo destinado ao repouso; $50 \%$ de acréscimo no valor das verbas incontroversas ${ }^{5}$, quando estas não são pagas na primeira audiência do processo trabalhista; um salário de multa no caso de pagamento das verbas rescisórias fora do prazo assinalado. Estas prestações geralmente são exigidas por ocasião da reclamação trabalhista, estando o trabalhador, quase sempre, demitido.

A fiscalização institucional a cargo do Ministério do Trabalho, analisada em seguida, detém competência para instrução, lavratura de auto de infração e aplicação de multas às empresas faltosas. AConsolidação das Leis do Trabalho-CLT, no mesmo capítulo que define direitos e deveres de empregados e empregadores, prevê as penalidades a serem aplicadas em caso de descumprimento dessas regras. Essa atividade fiscal possui natureza de Direito Administrativo e se constitui, portanto, em Direito Público. O valor das multas, que é fixado unitariamente, deve ser multiplicado pelo número de empregados em situação irregular, e aumenta, quando há reincidência. O Quadro 2 apresenta o montante das multas em aspectos selecionados das relações contratuais.

No caso da jornada de trabalho, por exemplo, uma empresa com até dez empregados que esteja descumprindo o teto de oito horas diárias (para um ou mais de seus empregados), será multada em $\mathrm{R} \$ 2.700,00$. Se, além disso, estiver burlando a legislação de horas extras, receberá 
outra multa no mesmo montante e assim por diante. Se reincidente, as multas dobram. Há ainda condutas tipificadas como infrações penais, a exemplo do crime de falsidade, relativo a declarações (pelo empregado) ou anotações (pelo empregador) fraudulentas na carteira de traba1 ho ${ }^{6}$. É de senso comum nos meios judiciais e trabalhistas a idéia de que as multas atendem ao princípio do razoável, sendo suficientes para inibir condutas faltosas, sobretudo nas pequenas e médias empresas. A questão, como já se disse, é saber qual a probabilidade do empregador ser apanhado caso resolva descumprir a lei.

\section{Quadro 2}

Multas Trabalhistas para Infrações Selecionadas

\begin{tabular}{|l|c|}
\hline Tipo de Infração & Multa \\
\hline $\begin{array}{l}\text { Jornada de trabalho (jornada máxima diá- } \\
\text { ria, jornada máxima semanal, turno no- } \\
\text { turno de 6 horas, horas extras etc.) }\end{array}$ & $\begin{array}{c}\text { De } \mathrm{R} \$ 2.700,00 \text { a } \mathrm{R} \$ 4.000,00 \text { por } \\
\text { ocorrência, dependendo do tamanho } \\
\text { da empresa }\end{array}$ \\
\hline Contratos temporários ilegais & $\mathrm{R} \$ 402,00$ por empregado \\
\hline
\end{tabular}

Fonte: DRT-Rio de Janeiro.

A sanção por não-cumprimento da legislação trabalhista pode vir de várias fontes, não necessariamente do poder público. Nos novos modelos de gestão da produção, por exemplo, em que a qualidade do produto final depende da coordenação de várias empresas em uma cadeia produtiva, as empresas contratantes podem exigir de suas contratadas a adesão a padrões de qualidade (do tipo International Organization for Standardization - ISO) que exigem condições dignas de trabalho e, por vezes, remuneração ${ }^{7}$. Do mesmo modo, empresas que operam no mercado internacional têm interesse em certificação de qualidade, que tem efeitos por vezes positivos sobre as condições de trabalho. Normas do mercado internacional também são um incentivo para se cumprir a lei. Os governos impõem barreiras a produtos de países que exploram o trabalho infantil ou escravo. Alegam dumping social contra países que remuneram mal a força de trabalho. Exigem atestados de adesão à legislação trabalhista para a aceitação de empresas em concorrências públicas. Mais e mais distribuidores (supermercados) estão adotando a norma de fair trade com países do Terceiro Mundo, impondo barreiras brancas via relações preferenciais com países que seguem as normas internacionais. Em alguns países, como o Brasil, grandes empresas devem, por lei, manter sistemas de saúde e segurança no trabalho, além 
de comissões de prevenção de acidentes. Por outro lado, os sindicatos também podem ter papel decisivo no aumento dos custos de não se cumprir a lei. O Ministério Público do Trabalho, quando ocorre ofensa a interesse coletivo dos trabalhadores, tem competência para instaurar inquéritos administrativos e firmar termos (e compromissos) de ajuste de conduta, que são documentos executáveis. Esses incentivos, porém, quase sempre se voltam para nichos de mercado, de difícil generalização para toda a economia. Em geral, incidem sobre empresas de grande porte, com sindicalismo consolidado e penetração no mercado internacional de produtos ou serviços. O principal agente da Inspeção do Trabalho no Brasil é mesmo o Ministério do Trabalho, através das Delegacias Regionais do Trabalho, que analisaremos na seção seguinte.

\section{BREVÍSSIMO HISTÓRICO}

Assim como o MTE, o sistema de vigilância e inspeção do trabalho no Brasil, passou por diversas fases ao longo de sua história, cuja origem pode ser delimitada em 1930, ano da criação do Ministério do Trabalho, Indústria e Comércio - MTIC pelo governo Getúlio Vargas. O próprio período varguista não pode ser tomado como uma fase única, uma vez que, à regulação que foi aos poucos sendo criada (ou modificada a partir da que já existia), se adicionou muito lentamente o aparato de fiscalização e repressão ao trabalho ilegal e/ou de incentivos para a adesão dos empresários à nova regulação.

A literatura sobre o tema é relativamente consensual ao mostrar, primeiro, a resistência empresarial em adotar a legislação trabalhista instituída pouco a pouco pelo governo $\operatorname{Vargas}^{8}$ e, em segundo lugar, a sempre resistente, porém gradual, adesão do empresariado à regulação, em parte porque ela mostrar-se-ia adequada à acumulação capitalista (Oliveira, 1972) e, em parte, por pressão dos governos posteriores a 1950 (Vargas inclusive) até 1964, em razão de sua maior permeabilidade às demandas sindicais.

O sistema de incentivos para a formalização das relações de trabalho restringiu-se, quase sempre, a multas para os casos desviantes, aos quais se chegava por denúncias dos trabalhadores e, mais ordinariamente, por meio de visitas "incertas" por parte do poder público, isto é, os fiscais do Ministério do Trabalho. Contudo, ainda sob a ditadura varguista, incentivos positivos não-monetários foram oferecidos aos empregadores que aderissem à ordem corporativa e à regulação do 
mercado de trabalho, como por exemplo a participação nos mecanismos bipartite de formulação da política industrial, o acesso a financiamento público e a preferência em concorrências públicas (Diniz e Boschi, 1976) ${ }^{9}$.

O sistema de regulação do mercado de trabalho não caiu com Vargas, como é sabido. Ao contrário, depois da promulgação da CLT em 1943, as normas de ordenamento das relações entre capital e trabalho revelar-se-iam longevas e, em certo sentido, pervasivas no mercado de trabalho urbano. É provável que, naquelas atividades onde o trabalho regulado era exigido, relacionadas com o emprego industrial urbano, a taxa de formalização das relações de trabalho fosse bastante alta, e talvez tenha ultrapassado os $50 \%$ já em meados da década de 1950 (Lobo, 2005).

A Convenção 81 da OIT, que regulamenta a inspeção do trabalho na indústria e no comércio, foi aprovada em 1956 por meio de Decreto Legislativo, e promulgada em junho de 1957 pelo presidente Juscelino Kubistchek através do Decreto $\mathrm{n}^{\circ}$ 41.721. Contudo, a primeira regulamentação sistemática da atividade data de 1965, ano da edição do Decreto Presidencial no 55.841, que instituiu o Regulamento de Inspeção do Trabalho - RIT ${ }^{10}$. Tudo indica que a edição desse regulamento respondeu à necessidade dos governos militares estar em dia com as convenções e determinações da OIT, que em 1947 editara sua Convenção 81. Não por acaso, em 1971, o governo Garrastazu Médici denunciou a Convenção por meio do Decreto Presidencial no 68.796, que seria revogado apenas em novembro de 1987.

Com a democratização dos anos 1980, abre-se a possibilidade de pressão dos agentes sociais sobre os mecanismos de inspeção. A Lei no 7.347, de 1985, autorizou o Ministério Público (entre outras entidades públicas e civis) a manejar as ações civis públicas, forma de ação coletiva de tutela de direitos coletivos e difusos. A Constituição de 1988 reforçou esse papel do Ministério Público, o que abre, em tese, a possibilidade de intervenção mais eficaz dos representantes de trabalhadores sobre suas próprias condições de trabalho. Os termos de ajuste de conduta operam como uma transação, em que o agente público ajusta com o agente privado a suspensão das autuações em troca do compromisso de correção das irregularidades encontradas, em um certo prazo. Se não for cumprido o compromisso, as multas previstas no termo são aplicadas, em um processo mais rápido, já que os termos são títulos 
executivos. A eficácia dessa via está por ser avaliada; por enquanto trabalhamos com o fato de que a inspeção sempre se baseou nas multas como instrumento de pressão. Ora, o recrudescimento do processo inflacionário depois de 1979 levou a uma rápida corrosão dos valores das multas previstos na CLT, cuja correção dependia, como ainda depende, dos humores do jogo parlamentar.

Nos anos 1990, a inspeção do trabalho voltou a ganhar centralidade. A principal inovação no sistema veio com a tentativa de se instituir a negociação em principal meio de solução de pendências decorrentes da inspeção do trabalho. Em julho de 1999, o MTE baixou Instrução Normativa, revista em 2001, regulamentando a constituição de "Mesas de Entendimento" para o caso de as fiscalizações do trabalho não resultarem em reparo imediato por parte do empregador. Essas Mesas devem ser chefiadas pelos chefes de fiscalização ou pelos próprios auditores fiscais, por delegação daquele, e os auditores podem convocar outros auditores para compor suas mesas. Podem convocar, também, entidades sindicais dos agentes envolvidos, mas não estão obrigados a fazê-lo. A instalação de uma Mesa de Entendimento deve ser comunicada ao Delegado Regional do Trabalho. A Instrução fixa prazos para a duração das mesas e outros procedimentos relevantes, porém dando liberdade de ação aos auditores fiscais na condução dos trabalhos, desde que informado o delegado regional do trabalho. Não se sabe, ainda, o impacto das mesas na eficácia do sistema, mas veremos que as estatísticas agregadas de inspeção do trabalho não sofreram grandes mudanças nos últimos anos, com exceção daquelas sobre recolhimento do Fundo de Garantia do Tempo de Serviço - FGTS.

\section{O Desenho do Sistema}

A estrutura atual do Ministério do Trabalho e Emprego pode ser apreendida observando-se o organograma a seguir, que dá uma idéia do lugar da inspeção do trabalho no conjunto de suas atividades. A Secretaria de Inspeção do Trabalho - SIT é uma das quatro secretarias executivas subordinadas diretamente ao gabinete do ministro. É, portanto, parte do segundo escalão burocrático do governo federal, e seu ocupante é nomeado diretamente pelo ministro. Além disso, trata-se de secretaria muito prestigiada e politicamente estratégica, pois tem ramificações em todo o território nacional através das Delegacias Regionais do Trabalho - DRTs, situadas no Distrito Federal e em cada estado da federação (27 ao todo), onde se dividem em subdelegacias (114 no país) 
Figura 1

Organograma do Ministério do Trabalho e Emprego - 2004

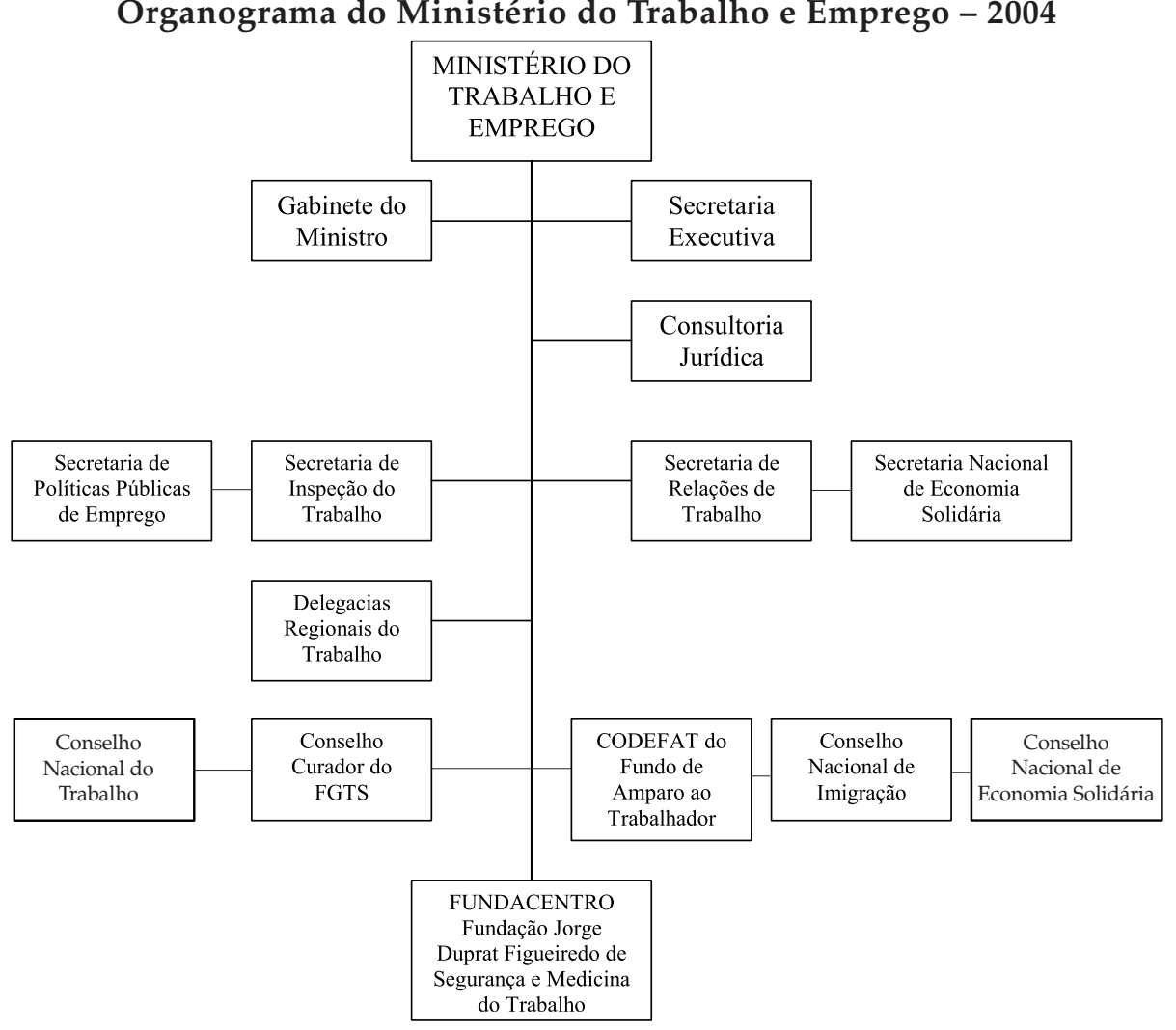

Fonte: www.mte.gov.br.

e, estas, em agências de atendimento (480 no total). Note-se que as DRTs estão ligadas diretamente ao gabinete do ministro. São elas as responsáveis pela execução das políticas formuladas no âmbito da SIT.

A Tabela 1 apresenta a evolução dos gastos do MTE nos últimos anos, bem como de sua participação no Orçamento Geral da União - OGU e no orçamento dos ministérios em particular ${ }^{11}$. Tomando-se o orçamento da União como um todo, a participação do MTE parece bastante acanhada, atingindo um máximo de $0,33 \%$ do total em 2003, embora os dados para este ano ainda não estivessem totalmente liquidados. Os dados também sugerem uma trajetória ascendente de participação a partir de 1998, quando atingiu-se o ponto mais baixo de presença do MTE nos gastos totais, de $0,14 \%$. A participação no orçamento geral dos ministérios também foi muito pequena em termos relativos, com pico de 1,16\% em 2003, ou 7\% se considerarmos o Fundo de Amparo ao Trabalhador - FAT. Note-se que, com o FAT, o orçamento consolidado do MTE vem aumentando sua participação relativa, que saltou de 5,8\% para $7 \%$ em nove anos. 
Tabela 1

Orçamento de Investimento do MTE e Participação no OGU e no Orçamento dos Ministérios

1995-2003

\begin{tabular}{|c|c|c|c|c|c|}
\hline Ano & $\begin{array}{c}\text { Ministério do } \\
\text { Trabalho }\end{array}$ & $\begin{array}{l}\text { Fundação Jor- } \\
\text { ge Duprat }\end{array}$ & FAT $\left(^{*}\right)$ & Total & $\begin{array}{c}\text { Deflator } \\
\text { (Índice Nacio- } \\
\text { nal de Preços } \\
\text { ao Consumi- } \\
\text { dor - INPC) } \\
\text { médio do ano) }\end{array}$ \\
\hline 1995 & 1.099 .553 .228 & 32.737 .644 & 9.015 .851 .714 & 10.148 .142 .586 & 0,57328 \\
\hline 1998 & 1.105 .748 .457 & 76.690 .048 & 11.859 .096 .374 & 13.041 .534 .880 & 0,63063 \\
\hline 2001 & 1.625.494.079 & 61.776 .345 & 13.427 .465 .653 & 15.114.736.078 & 0,75494 \\
\hline $2003(* *)$ & 2.878 .648 .569 & 38.693 .798 & 14.631 .865 .113 & 17.549.207.480 & 0,97304 \\
\hline $\begin{array}{l}\text { Participação no } \\
\text { OGU (\%) }\end{array}$ & \begin{tabular}{|c|} 
Ministério do \\
Trabalho
\end{tabular} & $\begin{array}{c}\text { Fundação Jor- } \\
\text { ge Duprat }\end{array}$ & FAT $(*)$ & Total & \\
\hline 1995 & 0,26 & 0,01 & 2,16 & 2,43 & \\
\hline 1998 & 0,14 & 0,01 & 1,50 & 1,64 & \\
\hline 2001 & 0,21 & 0,01 & 1,75 & 1,97 & \\
\hline 2003 & 0,33 & 0,00 & 1,68 & 2,02 & \\
\hline $\begin{array}{l}\text { Participação no } \\
\text { orçamento dos } \\
\text { Ministérios (\%) }\end{array}$ & $\begin{array}{c}\text { Ministério do } \\
\text { Trabalho }\end{array}$ & $\begin{array}{l}\text { Fundação Jor- } \\
\text { ge Duprat }\end{array}$ & FAT $^{(*)}$ & Total & \\
\hline 1995 & 0,63 & 0,02 & 5,18 & 5,83 & \\
\hline 1998 & 0,50 & 0,03 & 5,37 & 5,90 & \\
\hline 2001 & 0,65 & 0,02 & 5,37 & 6,04 & \\
\hline 2003 & 1,16 & 0,02 & 5,90 & 7,08 & \\
\hline
\end{tabular}

Fonte: Construído a partir dos microdados do OGU disponíveis em

http:/ / www.camara.gov.br/internet/orcament/Principal/exibe.asp?idePai=2\&cadeia=0@

(*) Fundo de Amparo ao Trabalhador.

${ }^{(* *)}$ Dados consolidados até setembro de 2003.

Na análise desses dados, é preciso considerar que, no OGU e no orçamento dos ministérios, se encontra a Previdência Social, a qual consome, sozinha, perto de metade do orçamento ministerial total e quase 14\% do OGU. Sem contar a Previdência, o MTE participava com cerca de $14 \%$ do orçamento dos ministérios em 2003, e estava em quarto lugar na dotação geral, aparecendo depois dos ministérios da Previdência, da Saúde e da Defesa, estando na frente inclusive do Ministério da Educação, com o qual alternou de posições algumas vezes nos últimos $\operatorname{anos}^{12}$. Outro ponto a se levar em conta é o de que o FAT, embora seja gerido por um conselho curador amplo, que inclui membros de outros ministérios, além de representantes de capital e trabalho tem a maior 
parte de suas políticas formuladas diretamente pelo MTE. Vale mencionar, dentre as mais importantes, a política nacional de qualificação de mão-de-obra, um dos carros-chefe da política de emprego do governo Fernando Henrique Cardoso, e o seguro-desemprego, que consome o maior volume de recursos do FAT (Lemos, 2003).

Analisando mais detidamente o orçamento do MTE de 2003, desagregado por Unidade Orçamentária e por função ${ }^{13}$, descobre-se que $38 \%$ dos recursos foram gastos com pessoal, considerando-se os servidores ativos e os inativos. As atividades-fim, ou seja, os gastos com investimentos propriamente ditos, não chegaram a $2 \%$ do total. É claro que pagamento de pessoal contempla uma parte significativa das atividades-fim, tal como a fiscalização do trabalho, já que esta implica a atuação direta dos fiscais junto às empresas. Além disso, cerca de $32 \%$ dos gastos com atividades-fim das secretarias couberam à SIT em 2003. Em 1995, esse montante fora de $22 \%$. Ou seja, nos últimos 8 anos, entre um quarto e um terço dos gastos com investimentos voltaram-se diretamente para a atividade de fiscalização. A inspeção do trabalho, pois, tem lugar de destaque no organograma e nos gastos do MTE.

A Constituição Federal de 1988 estabelece que compete à União organizar, manter e executar a inspeção do trabalho. O Regulamento da Inspeção do Trabalho - RIT é hoje o Decreto no 4.552, de dezembro de 2002, regulamentar da Lei no 10.593, do mesmo mês e ano. São normas recentes que reiteram o compromisso formal do país com a fiscalização do trabalho, em conformidade à Convenção 81 da OIT. O novo RIT firmou a terminologia "auditor fiscal do trabalho", em substituição a "inspetor do trabalho", para indicar o agente da inspeção do trabalho. Uma das mais importantes inovações deste regulamento é a ampliação da autonomia dos auditores, alcançada por sua subordinação diretamente à autoridade nacional ${ }^{14}$. Por fim, a CLT contém normas específicas sobre inspeção do trabalho, que estão em plena vigência, dentre elas o valor das multas a se aplicar no caso de irregularidades.

Ou seja, ainda que Organizações Não-Governamentais - ONGs, sindicatos e outras organizações da sociedade civil possam atuar como agentes de denúncias (Dal Rosso, 1997), a inspeção do trabalho, tal como definida em lei, é atividade de Estado vinculada ao Ministério do Trabalho e Emprego através da SIT. Esta divide-se em dois departamentos: (i) Departamento de Inspeção do Trabalho - DEFIT, responsável pelo planejamento e normatização das ações de fiscalização da le- 
gislação trabalhista; (ii) Departamento de Segurança e Saúde do Trabalhador - DSST, que coordena e normatiza as ações de fiscalização das normas de segurança e saúde no trabalho.

Em conformidade com as normas da OIT, a função fiscalizadora tem por finalidade promover o cumprimento da legislação. O poder de polícia autoriza o auditor-fiscal a "expedir notificações, embargar obras, interditar estabelecimentos, setores de serviços, máquinas ou equipamentos e, se necessário lavrar autos de infração, que são instrumento prévio para imposição de multa administrativa" (Silva, 2002). Tais providências são propostas pelo auditor-fiscal ao delegado regional, que decidirá, assinalando o prazo para cumprimento ${ }^{15}$.

A fiscalização atua em todo território nacional, em todas as empresas privadas urbanas ou rurais, bem como nas empresas estatais que têm empregados ${ }^{16}$. Em tese, também os escritórios dos profissionais liberais, as instituições filantrópicas, as associações recreativas e outras instituições sem fins lucrativos que têm empregados estão sujeitos à fiscalização, inclusive o trabalho doméstico. Mas veremos que isso não é viável.

Os auditores atuam na área geográfica da agência, subdelegacia ou delegacia onde estão lotados. Cumprem ordens de serviço que indicam as empresas que devem fiscalizar, mas podem ter iniciativa da fiscalização. A distribuição dos auditores fiscais pelas diferentes áreas de inspeção da mesma circunscrição ${ }^{17}$ obedece ao sistema de rodízio, efetuado em sorteio público, vedada a recondução para a mesma área no período seguinte. $\mathrm{O}$ ingresso no cargo de auditor-fiscal dá-se mediante aprovação do candidato em concurso público de provas, aberto a portador de diploma de curso superior. A nomeação para as áreas de segurança e medicina do trabalho exige, além da aprovação em concurso, comprovação de especialização - pós-graduação - em instituições reconhecidas oficialmente. Os delegados regionais do trabalho são nomeados por indicação política e não pertencem necessariamente à carreira de auditor-fiscal do trabalho. Cabe a eles aplicar as multas, com base nos autos de infração lavrados pelos auditores-fiscais ${ }^{18}$.

Os auditores são contratados pelo Regime Jurídico Único - regime estatutário - em que os salários são fixados em lei, e há garantia de estabilidade. Segundo dados do MTE, o salário de um auditor-fiscal em início de carreira pode chegar a US\$ 2.490 por mês, e a US $\$ 3.289$ no caso do nível mais alto da hierarquia funcional ${ }^{19}$. Esses valores são aproxi- 
mados, já que o que se recebe efetivamente ao mês depende do desempenho individual e do sistema como um todo. Assim, duas gratificações incidem sobre o salário básico: a Gratificação de Atividade Tributária-GAT, correspondente a 30\% do salário (ou 25\% do maior salário básico); e a Gratificação de Incremento da Fiscalização e da Arrecadação - GIFA, correspondente a $45 \%$ do maior salário básico de cada cargo. A GIFA comporta uma parcela relativa ao desempenho individual do auditor (um terço) e outra relativa ao desempenho global do sistema (dois terços). As metas de arrecadação que servem de base às gratificações são definidas nos Planos Plurianuais do governo federal, que têm duração de quatro anos. Essa estrutura salarial tem conseqüências decisivas para a eficácia e a efetividade da fiscalização, como veremos mais adiante.

Em tese, a inspeção do trabalho é detonada por dois procedimentos complementares: as denúncias e o sorteio de endereços para visita. $\mathrm{Na}$ prática, como as DRTs têm poucos fiscais para o número de denúncias que recebem ${ }^{20}$, a inspeção guia-se sobretudo por elas, que ocorrem em número suficiente para ocupar a agenda de inspeções. Conforme nos informa uma auditora-fiscal do trabalho entrevistada ${ }^{21}$,

"Atualmente, a grande maioria das fiscalizações é motivada por denúncias. O denunciante principal é o trabalhador individual, porém costuma-se priorizar o atendimento às denúncias dos sindicatos, do Ministério Público e da Polícia (nos casos de acidentes do trabalho). Embora a grande maioria das ações de fiscalização seja motivada por denúncias, é impossível atender a todas, não temos pessoal suficiente, por isso também se costuma priorizar entre os denunciantes individuais, aqueles que se identificam. Onde é possível, pode-se também organizar um programa para atender coletivamente, denúncias acerca de uma mesma empresa ou setor produtivo" (entrevista realizada em agosto de 2004).

Se da fiscalização resultar auto de infração, inicia-se um processo administrativo. Quando autuado, o empregador tem dez dias para apresentar sua defesa. Esgotado esse prazo, o processo - auto e defesa, ou somente o auto, se o empregador não apresentar defesa - é examinado por outro auditor-fiscal (diferente daquele que autuou) e é dado um parecer, que pode ser pela procedência total, parcial, ou improcedência da autuação. Essas peças são encaminhadas ao delegado ou subdelegado, para decisão. Se considerado "improcedente" o auto de infração, em primeira instância, é obrigatória sua remessa para análise em se- 
gunda instância; se confirmada a improcedência em segunda instância, o processo é arquivado. Se considerado "procedente", parcial ou totalmente, e o empregador pagar a multa no prazo de dez dias após recebida a notificação, terá desconto de $50 \%$ do valor estipulado. Caso não se conforme com a multa, o empregador tem prazo de dez dias para recorrer à segunda instância, mas deve depositar o valor integral da multa como requisito de apreciação do recurso. A segunda instância pode confirmar a multa - neste caso, o depósito converte-se em pagamento; ou aceitar o apelo do empregador que então receberá de volta o valor depositado. Se não pagar nem recorrer do valor da multa, o empregador é inscrito na dívida ativa da União, e a cobrança executiva será promovida pela Procuradoria da Fazenda Nacional, em processo junto à Justiça Federal. Todo esse procedimento administrativo deve durar, no máximo, sessenta dias, segundo determinação do RIT de 2002.

De acordo com auditores-fiscais entrevistados, apenas as pequenas e médias empresas costumam pagar as multas no início do processo, inclusive para aproveitar o desconto de 50\%. As empresas que contam com departamentos jurídicos normalmente recorrem das decisões. $\mathrm{O}$ recurso tramita primeiramente no âmbito administrativo. Findas todas as oportunidades de recursos, e recusado o pagamento, a cobrança segue para a Procuradoria da Fazenda Nacional. Importa notar que essa procuradoria está envolvida na cobrança da dívida ativa de valores muito mais significativos do que os das multas trabalhistas. Com isso, ainda segundo funcionários das DRTs, haveria pouco incentivo para a cobrança e grande chance de prescrição da dívida. E nunca é demais lembrar que, findo o processo administrativo, a parte pode recorrer ao Poder Judiciário, em que os prazos podem se estender indefinidamente.

O desenho do sistema, pois, obedece às recomendações da OIT quanto à existência de mecanismos que garantam a independência técnica dos fiscais e assegurem condições adequadas para sua atuação. Mesmo considerando as restrições quanto à execução das penas, o Brasil está mais bem aparelhado do que alguns de seus vizinhos latino-americanos, como a Argentina e o México, por exemplo. Neste último país, a inspeção tem duas jurisdições, uma nacional e outra no Distrito Federal - DF, o que gera disputas por competências e âmbitos de atuação, reduzindo a eficiência e a eficácia do sistema. Os salários, mesmo do pessoal graduado (médicos e engenheiros), não ultrapas- 
sam US\$ 750 para a jurisdição nacional, chegando a US\$ 550 no DF. Aqui, há apenas três computadores para os auditores-fiscais, que não dispõem de veículos para deslocamento até os locais de trabalho. Além disso, o número de fiscais é muito pequeno e vem caindo bastante nos últimos anos. Em 1994, na jurisdição federal eles eram 388, caindo para 181 em $2004^{22}$. Na Argentina, não se exige diploma de nível superior dos inspetores, que têm, em média, onze anos de estudo. Além disso, eles não têm uma carreira própria no funcionalismo público, e nem todos estão protegidos por contratos que assegurem estabilidade no emprego, como recomenda a OIT (Palomino e Senén, 2005).

\section{RESULTADOS DA INSPEÇÃO}

A Tabela 2 mostra os dados consolidados da fiscalização do trabalho no Brasil. O primeiro fato a salientar é a queda acentuada no número de fiscais de 1990 a 1995, período quando se atingiu o menor número de profissionais, pouco menos de 2 mil pessoas. Em 1996, houve um salto significativo de mais de oitocentos novos fiscais, mas seu número vem caindo desde então. O segundo ponto a marcar é que a variação no número de fiscais não parece ter relação com o número de empresas visitadas ou de trabalhadores atingidos. Ao contrário, o ano com menor número de fiscais (1995) é também aquele com o maior número de empresas atingidas pela fiscalização, mais de $420 \mathrm{mil}$, com média de 215 empresas por fiscal. Na verdade, a se fiar nesses dados (mas comentamos esse problema em seguida), tudo indicaria que o sistema se tornou mais eficiente quanto menor o número de fiscais. Isso leva à terceira observação relevante aqui. A fiscalização vem mudando de rosto nos últimos anos, atingindo mais trabalhadores em um menor número de empresas, o que resulta no aumento do tamanho médio das empresas visitadas a partir, grosso modo, de 1997. Menos empresas visitadas por um número menor de fiscais, mas atingindo mais trabalhadores a cada ano significa exatamente isso: maior eficiência da ação fiscal, e também maior efetividade, uma vez que mais trabalhadores são atingidos.

Um quarto ponto a salientar tem a ver com a eficácia da ação fiscal, expressa no número de autuações, no de trabalhadores registrados em razão da fiscalização e na Taxa de Regularização em Estabelecimentos Fiscalizados - TREF que expressa a taxa de adequação das empresas à legislação trabalhista. Uma vez mais a se crer nos dados disponíveis, entre $16 \%$ e $30 \%$ das empresas visitadas foram autuadas a cada ano, resultando em nunca menos do que 250 mil trabalhadores registrados 
A Inspeção do Trabalho no Brasil

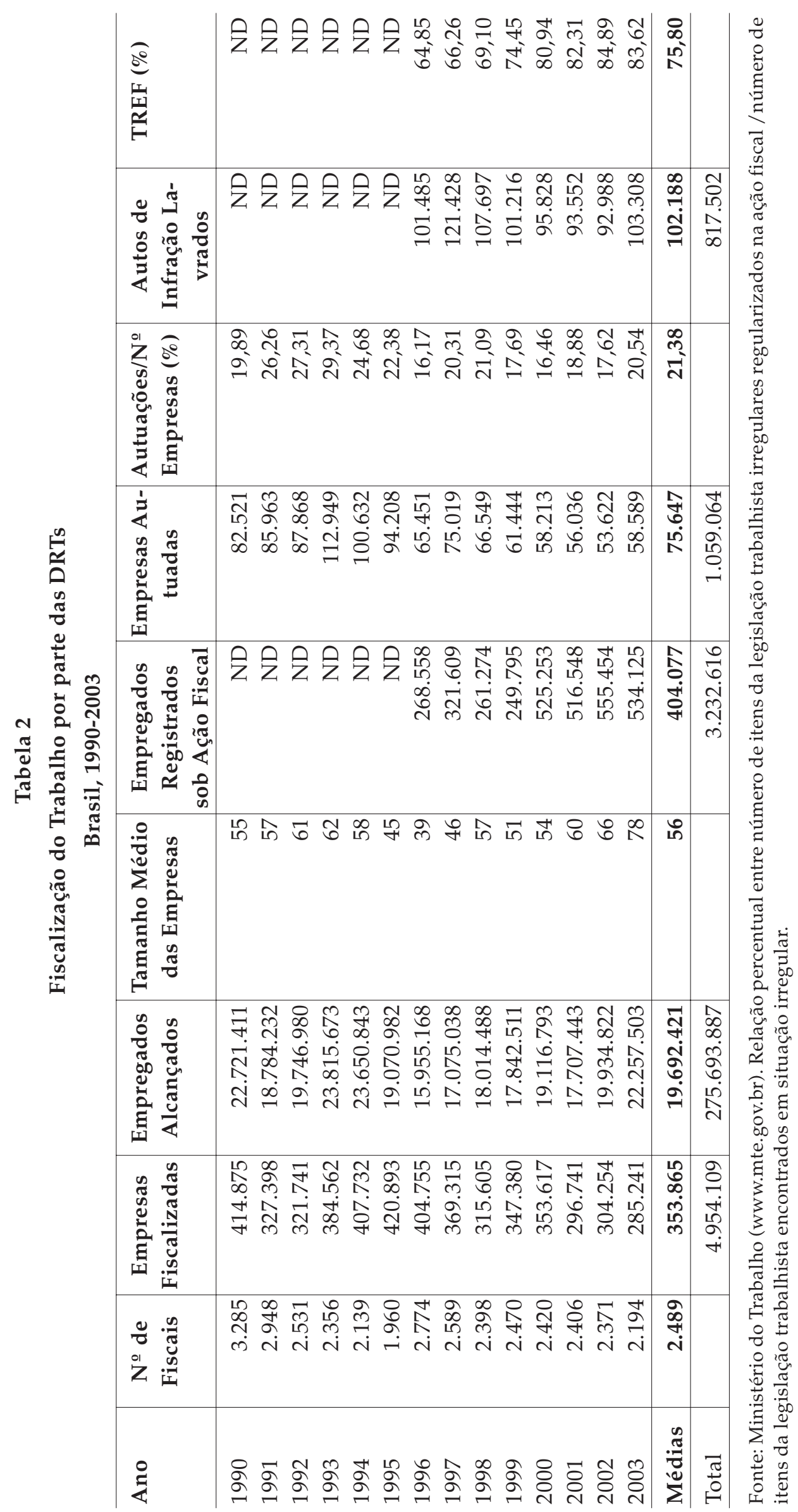


sob ação fiscal, isto é, vínculos empregatícios formalizados a partir de 1996 (não há dados disponíveis para os anos anteriores nesse quesito específico). A tabela não mostra, mas isso representou, em 2001, o pico de 2,92\% do total de trabalhadores atingidos pela fiscalização, para uma média de 1,17\% no período. E a taxa de regularização alcançada, isto é, a proporção de itens irregulares regularizados após a ação, também aumentou significativamente ao longo dos anos, passando de 65\% em 1996 para 84\% em 2003. Em suma, por esses dados somos levados a crer que o sistema parece caminhar para um desenho mais enxuto e mais eficaz em termos de regularização das relações de trabalho.

É preciso ler a Tabela 2 com cautela, porém. A aparente eficiência do sistema é contra-arrestada pela paradoxal circunstância de que apenas 1,17\% dos vínculos teriam sido regularizados com a ação fiscal, ao passo que $21 \%$ das empresas visitadas teriam sido autuadas em todo o período (1990-2003). Ora, a taxa de autuação é muito alta (um quinto do total das empresas), mas a de regularização de vínculos empregatícios é muito baixa (1,17\% dos trabalhadores atingidos). Isso pode estar refletindo uma de três coisas: primeiro, que em uma mesma empresa nem todos os trabalhadores estão irregulares, de sorte que muitos são atingidos, mas apenas alguns regularizados; em segundo lugar, que as irregularidades e autuações ocorrem sobretudo em empresas de menor porte, o que resulta em menos pessoas atingidas, apesar do alto contingente de empresas autuadas; em terceiro, que a inspeção do trabalho visa sobretudo a outros objetivos (como o recolhimento do FGTS ou a saúde e segurança no trabalho) que não a regularização do vínculo empregatício. Tomadas em conjunto, essas três alternativas denotam um sistema de fiscalização que se restringe ao mercado formal de trabalho. Para deixar o argumento mais claro, basta ler os dados ao revés. Supondo eficaz a ação fiscal, isto é, que um vínculo irregular é sempre regularizado em função da fiscalização, se apenas 1,17\% dos trabalhadores atingidos tiverem seus vínculos regularizados, então os outros $98,83 \%$ estarão em situação regular. Como o emprego assalariado sem carteira representou, ao longo da década de 1990, entre 35\% e $45 \%$ do mercado de trabalho assalariado no Brasil, então a conclusão necessária é a de que o sistema de fiscalização está mirando as empresas erradas, ao menos no que respeita a esse aspecto específico da inspeção, ou seja, a regularização do vínculo trabalhista.

Dizendo de outra maneira, o mercado de trabalho de assalariados sem carteira ocupou, na década de 1990, entre 10 e 15 milhões de pessoas, se- 
gundo dados da Pesquisa Nacional por Amostra de Domicílios-PNAD. Como a fiscalização atingiu duas vezes essa proporção de pessoas, e como encontrou não mais do que 1,17\% em média de trabalhadores em situação irregular, somos levados à conclusão de que a fiscalização não incidiu sobre aqueles 15 milhões de assalariados sem carteira, mas sim sobre os mais de 25 milhões de assalariados com carteira, o que resultou na baixíssima taxa de registro dos trabalhadores atingidos.

Ainda assim, é provável que os dados do MTE estejam superestimando o universo coberto e, também, a taxa de eficácia da fiscalização. Isso porque o número de trabalhadores atingidos parece muito alto tendo em vista o mercado formal de trabalho no país, que variou entre 20 e 29 milhões de empregados entre 1990 e 2003, segundo dados do próprio MTE. Como a fiscalização parece mirar as grandes empresas ${ }^{23}$, sua efetividade média, isto é o número de trabalhadores atingidos dividido pelo de trabalhadores formais existentes, seria, por vezes, superior a $80 \%$ do mercado formal de trabalho ${ }^{24}$, o que parece inteiramente disparatado em um sistema em que todos reclamam de sua baixa eficácia e cobertura.

Em segundo lugar, o sistema de remuneração e de prêmios dos fiscais está lastreado no número de trabalhadores atingidos, no número de carteiras de trabalho registradas e na quantidade de recursos do FGTS arrecadados. Esse sistema de metas contribui para que os fiscais superestimem a eficácia de sua ação e, também, as estatísticas. Como disse uma auditora-fiscal do trabalho de São Carlos,

"A empresa pequena representa, em termos de produtividade, muito pouco para o fiscal. Ou seja, quanto menor é o número de empregados de uma empresa, menor a 'pontuação' atribuída pelo nosso sistema de avaliação (ao qual está condicionada a recepção de nosso salário integral). Assim, se fiscalizamos empresas pequenas, temos que trabalhar mais e mais rapidamente. Como isso é muito difícil, fica mais simples lavrar um auto de infração e ir embora sem alterar a situação da empresa (ou até piorando-a). É bom lembrar que as metas a que somos submetidos também apontam nessa direção, temos que fiscalizar muito e rápido. Se os problemas detectados são resolvidos ou não parece, não interessar muito" (entrevista realizada em agosto de 2004).

Ou seja, o próprio salário está condicionado às quantidades atingidas. Com isso, o sistema oferece incentivos para que o foco da fiscalização se dirija às grandes empresas. Além disso, mesmo que pequenas em- 
presas sejam fiscalizadas, ao auto de infração nem sempre se seguirão medidas destinadas a sanar a situação irregular. Por fim, como afirma um auditor-fiscal do Rio de Janeiro, é comum que empresas visitadas mais de uma vez no âmbito de uma fiscalização e seus desdobramentos sejam contadas tantas vezes quantas forem as visitas, inflando as estatísticas.

É bom deixar claro que as metas de fiscalização aludidas pela auditora de São Carlos referem-se à arrecadação do FGTS. Segundo documento do MTE (2004), a partir de 1996, as metas de arrecadação passaram a ser definidas pelo Ministério da Fazenda, no âmbito do plano de metas do governo federal, sendo parte do esforço fiscal da administração pública. O mesmo auditor-fiscal do Rio de Janeiro citado anteriormente informa que, desde então, este passou a ser o foco central da inspeção do trabalho no Brasil.

E de fato, a Tabela 3 mostra que, de 1997 em diante, nunca menos do que 3\% da arrecadação total do FGTS decorreu da ação fiscal, chegando em 2002 a quase um bilhão de reais arrecadados (ou 4,3\% do total). Trata-se de um montante equivalente a $60 \%$ do orçamento do Ministério do Trabalho em 2003 (1,6 bilhão de Reais). A tabela mostra, também, que a eficiência da arrecadação vem aumentando, pois o montante médio arrecadado por notificação lavrada saltou de R\$ 24 mil em 1996 para quase R\$ 63 mil em 2002.

Tabela 3

Fiscalização do FGTS - Brasil, 1996-2002

\begin{tabular}{l|c|r|r|r|r}
\hline Ano & $\begin{array}{c}\text { Arrecadação } \\
\text { Bancária do } \\
\text { FGTS (A) }\end{array}$ & $\begin{array}{c}\text { Notificações } \\
\text { Lavradas (B) }\end{array}$ & $\begin{array}{c}\text { Total Recolhido } \\
\text { sob Ação Fiscal } \\
\text { (C) }\end{array}$ & (C)/(B) & (B)/(A) \\
\hline 1996 & $11.671 .686 .175,56$ & 9.385 & $228.404 .462,40$ & $24.337,18$ & 1,96 \\
1997 & $12.925 .111 .506,46$ & 19.040 & $450.238 .529,74$ & $23.646,98$ & 3,48 \\
1998 & $16.781 .697 .816,92$ & 18.709 & $550.591 .181,65$ & $29.429,21$ & 3,28 \\
1999 & $17.408 .212 .152,04$ & 17.062 & $614.837 .075,20$ & $36.035,46$ & 3,53 \\
2000 & $18.708 .530 .527,10$ & 16.316 & $822.664 .678,16$ & $50.420,73$ & 4,40 \\
2001 & $21.074 .052 .206,15$ & 15.523 & $737.000 .126,18$ & $47.477,94$ & 3,50 \\
$2002\left(^{*}\right)$ & $22.482 .012 .000,00$ & 15.328 & $960.569 .409,70$ & $62.667,63$ & 4,27 \\
\hline
\end{tabular}

Fonte: Ministério do Trabalho (www.mte.gov.br).

$\left.{ }^{*}\right)$ Estimativa. 
Esses dados, em conjunto com a TREF da tabela anterior, reforçam o argumento de que, em resposta aos incentivos que oferece aos auditores, o sistema está sendo direcionado para empresas cada vez maiores. A mesma auditora citada antes disse que

“[...] a empresa grande é muito mais organizada, e o atendimento ao Ministério do Trabalho, em geral, é profissional. Na parte documental, quase sempre, a empresa já tem os documentos e programas legalmente exigidos e em caso de discordância ou mesmo de uma irregularidade detectada na inspeção, teremos interlocução com a empresa, ou seja, mesmo que decidamos pela lavratura de um auto de infração, sabemos que podemos dar continuidade à fiscalização até a regularização do problema, o que normalmente, se consegue dentro dos prazos estabelecidos. E mesmo se houver necessidade de grandes investimentos, como no caso de exigência de reformas, construções ou contratação de pessoal, também é muito mais fácil, com a empresa grande, lançarmos mão de outros recursos como mesa de entendimento, estímulo de acordos com os representantes da categoria profissional etc." (entrevista realizada em agosto de 2004).

Como se pode ver, a fiscalização nas empresas maiores é também mais eficaz, por várias razões correlatas: as empresas são "mais organizadas", atendem ao MTE de forma "profissional", têm recursos financeiros para responder às exigências e eventuais autuações - o que resulta em melhor produtividade para os fiscais - fazem-no "dentro dos prazos" etc. Tudo conspira para que a inspeção privilegie estas às outras empresas, e isso deve estar se refletindo nas melhores taxas de regularização dos últimos anos.

O foco nas empresas maiores decorre, também, do fato de o MTE operar com um conjunto enviesado de informações cadastrais, que privilegia as empresas formalmente estabelecidas. $\mathrm{O}$ cadastro que serve de base para a inspeção é construído a partir da Relação Anual de Informações Sociais - RAIS, à qual são acrescentadas informações das pesquisas econômicas do IBGE e outras fontes, que cobrem principalmente o mercado formal de trabalho. $\mathrm{O}$ acesso a empresas informais, quando ocorre, resulta sobretudo das denúncias. Mas parece plausível suspeitar que, quanto mais precário o mercado de trabalho e maior a taxa de desemprego, menores os incentivos para que os trabalhadores denunciem más condições de trabalho. O caso da construção civil do Rio de Janeiro, analisado em seguida, é exemplo claro desse limite. 


\section{INSPEÇÃO DO TRABALHO NA CONSTRUÇÃO CIVIL DO RIO DE JANEIRO}

Quais as chances de que a burla da lei por uma empresa seja descoberta e, depois, sancionada? A construção civil é um setor estratégico para a resposta a essa pergunta. Ali, o trabalho é, tradicionalmente, precário, com altas taxas de ilegalidade e de trabalho autônomo. Além disso, o setor apresenta uma das maiores taxas de acidentes de trabalho do país, o que denota condições precárias e perigosas de trabalho ${ }^{25}$, objeto rotineiro da inspeção. No que se segue, dois aspectos centrais serão avaliados: de um lado, o poder fiscal do Estado e, de outro, a atuação dos sindicatos de trabalhadores e empregadores como agentes ou intermediários da fiscalização. Os temas centrais a tratar serão os custos de contratação e demissão, além do reconhecimento do vínculo empregatício via registro em carteira de trabalho.

\section{Sobre Chances de Ser Apanhado}

A fiscalização do trabalho na construção civil do Rio de Janeiro tem dois mecanismos propulsores básicos. Primeiro, o início de uma obra, quando os condomínios ${ }^{26}$ devem prestar ao Ministério do Trabalho, ao sindicato (por exigência da convenção coletiva) e à prefeitura da cidade, um conjunto de informações sobre duração da obra, empresas envolvidas no condomínio, trabalhadores empregados etc. Em segundo lugar, através de denúncias dos trabalhadores, feitas por meio de um número de telefone específico para isso no sindicato de empregados, em que o trabalhador pode denunciar anonimamente. O sindicato recebe de 80 a 100 denúncias por mês. Oito equipes fixas de fiscais - que podem chegar a 15 se todos os dirigentes saírem para fiscalizar - trabalham todos os dias da semana visitando obras segundo uma programação previamente definida com base na triagem e hierarquização das denúncias. Hoje, há algo como 8 mil canteiros registrados ou conhecidos no Rio de Janeiro. É verdade que o registro formal da obra na prefeitura e no sindicato é uma obrigação legal difícil de se elidir no caso das obras maiores e mais visíveis, mas edificações menores e, sobretudo, as reformas, nem sempre podem ser identificadas e, portanto, fiscalizadas.

Vejamos como funciona o primeiro mecanismo, as visitas no início das obras registradas. Segundo um diretor de fiscalização do sindicato, este não visita de surpresa:

“Nós temos um procedimento regulado. As empresas grandes nos informam no início e no final da obra, protocolam no sindicato e no Mi- 
nistério do Trabalho. Então, quando vai começar uma obra nós enviamos um ofício de 'Visita Técnica Orientativa', com a finalidade de levantar possíveis pendências naquele canteiro e levar o trabalho da diretoria para aqueles trabalhadores. Levamos nosso check list, vemos as pendências e damos 5 dias para arrumar o que tiver que ser arrumado. Voltamos, foi atendido? Ótimo. Não foi? Então a gente manda um ofício solicitando que compareçam aqui à entidade para uma Mesa de Entendimento, composta pelo diretor da pasta e um representante daquela equipe que visitou o canteiro com a notificação na mão. E tentamos adequar a empresa à legislação e à convenção coletiva de trabalho, evitando ao máximo levar isso à Justiça do Trabalho. Esgotamos todas as possibilidades de negociação, até para manter um relacionamento de parceria" (entrevista realizada em julho de 2004).

Procedimento "regulado", aqui, quer dizer três coisas primordiais: primeiro, que as regras de fiscalização são acordadas com o sindicato patronal; em segundo lugar, que as empresas são informadas sobre a fiscalização; terceiro, que há um inventário de itens a se fiscalizar, que é previamente conhecido pelas empresas, nomeado pelo sindicalista como "check list". Esse inventário é, também, uma forma de dar tempo (5 dias) à empresa para que ela se adapte às regras. Caso isso não ocorra, uma série de outros procedimentos negociais são acionados, a começar por uma "mesa de entendimento" no sindicato laboral, onde se busca um acordo para adequação da empresa à lei e à convenção coletiva. Caso isso continue não funcionando, há a Justiça do Trabalho como último (e indesejado) recurso.

A palavra-chave para os dirigentes sindicais de trabalhadores e patrões é, indubitavelmente, parceria. Ela opera também no segundo mecanismo detonador da fiscalização. Nas palavras do mesmo sindicalista,

“[...] a outra forma de fiscalizar é quando vem a denúncia por parte de um trabalhador. Aí nós pegamos o endereço daquele canteiro, levantamos o número do telefone, geralmente são empresas cadastradas conosco, e mandamos um ofício de 'Visita Técnica Orientativa'. Avisamos que vamos fazer uma visita para orientar sobre a segurança no trabalho. A gente não chega de surpresa. Porque isso não interessa a ninguém, certo? O que a gente quer é o direito do trabalhador respeitado, certo? Então, chegando lá eu vou constatar o problema com certeza, o que o trabalhador denunciou vai aparecer. Agora, a gente nunca diz que foi lá por denúncia do trabalhador, para não expor nem prejudicar o trabalhador" (entrevista realizada em julho de 2004). 
Em boa parte das fiscalizações, decorrentes de denúncia ou automáticas em razão do início de uma obra, um membro do Sindicato da Indústria da Construção Civil - SindusCon, sindicato patronal, faz parte da equipe de visitas. Segundo um dirigente patronal entrevistado, a parceria é vantajosa para os dois lados, porque interessaria ao SindusCon a obediência às normas de segurança no trabalho, que ajudam a reduzir o número de acidentes ${ }^{27}$. As fiscalizações contam ainda, embora nem sempre, com um agente da Delegacia Regional do Trabalho. Isso, segundo os sindicalistas, torna as visitas mais eficazes. O delegado regional tem poderes para lacrar a obra imediatamente se for o caso, se houver, como disse um dirigente, "um descalabro muito grande, e a empresa não quiser acertar aquilo na hora". Além disso, o delegado éo agente executor por excelência do Ministério do Trabalho. Sua presença traz maior densidade às equipes de fiscalização. Por fim, sua presença, juntamente com representantes de trabalhadores e patrões, inibe (ao menos idealmente) práticas pouco ortodoxas ou abertamente corruptas por parte de qualquer um dos três agentes.

É claro que tudo isso são discursos de dirigentes, não podem ser tomados pelo valor de face. O sindicato não dispõe de um registro confiável das visitas, nem de seus resultados em termos de atenção a normas de segurança no trabalho e ao direito do trabalho, dados que permitiriam uma real mensuração da melhoria na eficácia ou efetividade da fiscalização ao longo do tempo. Em 2003, segundo um dirigente, entre março e junho foram computados mais de trezentos novos registros em carteira decorrente das fiscalizações, mas não há como saber se esse número é grande ou pequeno historicamente. Ele certamente parece pequeno tendo em vista os mais de $100 \mathrm{mil}$ trabalhadores informais estimados para $2002^{28}$, ou mesmo tendo em vista os 32 mil trabalhadores assalariados sem carteira assinada. Ao ritmo da fiscalização de 2003, seriam necessários mais de 25 anos para registrar todos os assalariados sem carteira existentes, sem contar que novos vínculos sem registro nascem todos os dias no mercado de trabalho da construção civil. Nada assegura que um vínculo registrado hoje continuará assim amanhã.

No ambiente de trabalho na construção civil, em que a construtora principal de um condomínio quase nunca é a maior empregadora, estando os empregados distribuídos por até dezenas de subcontratadas, a eficácia da fiscalização depende da capacidade do sindicato chegar às franjas da teia de terceirizações. Para isso, o sindicato adota a estratégia de não negociar com as terceirizadas, e sim com a empresa princi- 
pal do condomínio. Aspecto importante é o fato de esse procedimento constar de convenção coletiva de trabalho, isto é, cabe à empresa principal zelar pelo cumprimento da legislação e da convenção coletiva pelas contratadas. Isso reforça o que disse um dirigente patronal, fala referendada por uma juíza de direito: a jurisprudência consolidada de se julgar a empresa principal responsável subsidiária (vinculada) pelas demais acaba forçando as empresas a exercer alguma vigilância sobre as subcontratadas. Isso nem sempre é possível, obviamente.

Com efeito, conforme um diretor de fiscalização, a grande barreira ao trabalho de inspeção, tanto por parte do sindicato quanto por parte dos auditores fiscais do trabalho, é a escala do negócio, ou seja, sua baixa capitalização. Esta impõe barreira econômica eficaz, porque a autuação rigorosa poderia inviabilizar o negócio, extinguindo postos de trabalho. É, assim, mais uma componente que se vem somar aos incentivos institucionais e legais para que, como vimos, a fiscalização seja majoritariamente efetuada em empresas médias ou grandes. A opção tem sua racionalidade. Segundo dados do Censo 2000 para a cidade do Rio de Janeiro, 64\% das pouco mais de 3 mil pessoas que se disseram empregadoras tinham empresas com até dez empregados. Tomando-se os dados da RAIS para 2002, que mede apenas o emprego registrado em carteira, a proporção de empresas com até dez empregados era de $70 \%$ sobre o total das 3.156 empresas formalmente registradas, e de $82 \%$ se tomarmos as empresas com até 19 empregados. Contudo, a proporção de trabalhadores ocupados em empresas com até 19 empregados era de apenas 20,6\% segundo a mesma RAIS. Na outra ponta, empresas com 50 empregados ou mais eram apenas $33,1 \%$ do total, mas ocupavam $61,3 \%$ da força de trabalho com registro em carteira. Considerando que as chances do sindicato ou do MTE chegar em uma empresa para fiscalizar é tanto maior quanto mais formal ela for, isto é, quanto mais facilmente ela possa ser encontrada - tenha um telefone e um endereço que possam ser rastreados de alguma maneira, seja nos arquivos do sindicato, seja nos cadastros de empresas do IBGE - então é de se supor provável que sindicato e MTE estejam cobrindo menos de um terço das empresas realmente existentes (se somarmos os setores formal e informal), mas tendo quase dois terços da força de trabalho empregada como universo potencial de ação.

Pode-se dizer, então, que as chances de ser apanhado em caso de desrespeito à lei não são nulas na construção civil do Rio de Janeiro, e nem muito altas, exceto no caso das grandes obras, dos grandes canteiros de 
obras ou das obras em lugares muito visíveis, caso das reformas nos edifícios do centro da cidade, por exemplo. Em uma escala de 0 a 100, a chance de um grande canteiro de obras ser fiscalizado, tendo sido denunciado, é de 100. Essa chance decresce à medida que diminui o tamanho da obra e sua visibilidade social. Na outra ponta, a chance de uma pequena obra tocada por um pequeno construtor (uma reforma, a construção de casas de campo ou mesmo na cidade) ser fiscalizada pelo sindicato ou pela DRT, mesmo que tenha sido denunciada, é de 0 , ou muito próxima disso. A fiscalização potencial, pois, é função direta do tamanho da obra e das empresas nela envolvidas, e do fato de haver ou não uma denúncia. A questão central, então, torna-se saber qual a chance real de que um direito burlado suscite uma denúncia.

Essa chance não está aleatoriamente distribuída na população empregada. Alguns trabalhadores são mais propensos que outros a fazer uma denúncia. Esta é uma função direta do conhecimento dos direitos e inversa do receio de que ela possa resultar na perda do emprego, ponderado pelo custo do desemprego para o trabalhador individual. Em situações de alto desemprego, mesmo um receio pequeno pode ser suficiente para não levar à denúncia, por mais que os trabalhadores conheçam seus direitos. A confiança de que a denúncia terá garantia de anonimato - caso do telefone específico para isso no sindicato, o disque-denúncia - pode não ser suficiente para suplantar o receio de perda de emprego em situações de fragilidade de mercado.

\section{Sobre Chances de Ser Punido}

O conflito trabalhista resultante de lesão a direitos tem três momentos principais de encaminhamento, cada qual associado a uma instituição, como se segue: 1) momento da regulação das normas e fiscalização de sua observância pelas empresas, sob responsabilidade do Ministério do Trabalho e Emprego; a própria fiscalização induz à adequação das empresas às normas; 2) a resistência ou recalcitrância no cumprimento das normas abre um processo de negociação no sindicato ou na DRT, ou em ambos; tal processo tanto pode ser conduzido pelas delegacias regionais do trabalho como pelo Ministério Público do Trabalho, em sua competência de instalar inquéritos civis e firmar termos de ajuste de conduta que, já vimos, são títulos executáveis;3) a insuficiência dos instrumentos já citados leva os contendores à Justiça do Trabalho, portanto, ao Poder Judiciário. 
A presença do delegado regional do trabalho ou outro profissional da DRT facilita a primeira solução, mas a DRT tem poucos profissionais, não podendo atender a todos os chamados da construção civil. Logo, as opções 2 e 3 estão quase sempre no horizonte de cada fiscalização. Na verdade, segundo dirigentes dos sindicatos de patrões e empregados, o acordo é o objetivo sempre visado, e ele ocorre, em geral, nas Mesas de Entendimento - ME, para o caso de fraudes na segurança do trabalho, ou na Comissão de Conciliação Prévia da Construção Civil CCP-CC, um mecanismo que, como em outros casos, vem funcionando como a primeira instância real de solução de conflitos relativos à vigência ou, principalmente, à rescisão dos contratos.

No caso dos problemas de segurança e saúde no trabalho, as soluções ou são imediatas, no local de trabalho, ou nas ME. A terceira opção é quase sempre ineficaz. Um dirigente sindical da construção civil afirma, categoricamente, que a Justiça do Trabalho e o Ministério Público do Trabalho são muito lentos, tendo em vista a duração de uma obra, que pode variar de três meses a um ano, chegando raramente a três anos. Segundo ele, "Quando a Justiça decide agir a obra já acabou, entendeu?". Contudo, o mesmo dirigente afirma que as empresas costumam respeitar a regulação de segurança no trabalho, porque "ninguém quer ficar com o nome sujo na praça, a pecha de que trabalha inseguro". Ademais, uma parte não desprezível das empresas formalmente estabelecidas tem certificação ISO, cujos parâmetros incluem segurança no trabalho e benchmarking para acidentes. Já vimos que um diretor do sindicato patronal tem a mesma visão do problema. E o dirigente trabalhador completou: “Uma grande empresa que tem certificação não aceitará empreiteiras em sua obra que não sigam as normas".

O problema, obviamente, são as grandes empresas que não têm certificação, e as pequenas e médias que o sindicato não chega a fiscalizar, porque trabalham na informalidade. De todo modo, sindicalistas de ambos os lados asseguram que, com a parceria que estabeleceram sobre esse e outros assuntos, a segurança no trabalho na construção civil do Rio de Janeiro melhorou muito nos últimos anos, a ponto de em 2004 ter-se registrado, até julho, apenas um acidente fatal.

Infelizmente, não foi possível ter acesso a dados consolidados sobre a evolução dos acidentes de trabalho na construção civil da cidade do Rio de Janeiro que permitissem comprovar as afirmações colhidas nas 
entrevistas ${ }^{29}$. O certo é que dados oficiais - que são sempre subestimados, tanto mais quanto mais informal for o setor econômico ${ }^{30}-$ apontam para pouco mais de 1.700 acidentes de trabalho na construção civil no Estado do Rio de Janeiro (de que a capital tem quase metade da população) em 2000, e o setor é o que mais contribui, historicamente, para as estatísticas de acidentes de trabalho em geral no Estado, e também para a sub-representação das estatísticas.

No caso dos direitos relativos à vigência do contrato de trabalho, e sobretudo das rescisões contratuais, o principal mecanismo de encaminhamento dos conflitos é a CCP-CC. Sua atuação tem impacto de monta sobre os custos de se cumprir ou não a legislação, principalmente aquela relativa às despedidas. A CCP-CC é composta por representantes dos sindicatos de patrões e empregados. Por lei, antes de serem encaminhadas à Justiça do Trabalho, as queixas trabalhistas devem passar, primeiro por uma Comissão de Conciliação Prévia - CCP, se no local houver sido instituída a Comissão no âmbito da empresa ou do sindicato da categoria. Logo, a CCP-CC, como todas as outras, foi convertida em uma espécie de tribunal do trabalho sem um juiz para presidi-lo e julgar as causas. Transcrevemos um trecho de entrevista de um dirigente sindical que participa da CCP, instrutivo em muitos sentidos:

“Temos nossa CCP onde discutimos essas questões também, como FGTS. Porque às vezes a empresa quer pagar [as verbas rescisórias], só que não tem como. Então a gente instrui o trabalhador a fazer um acordo. Isso durante a demissão ou mesmo durante o contrato ainda em vigência. [...] Hoje as CCP desafogaram a Justiça do Trabalho. A maioria das empresas que procuravam fazer esses acordos na justiça hoje fazem na CCP. Nós implantamos uma norma na CCP que nenhum trabalhador pode receber menos de $60 \%$ do que ele tem direito. Não pode ser acordado menos de $60 \%$. Norma criada pelo sindicato. Agora, se o trabalhador quer fazer uma rescisão de contrato, ele vai assumir o risco daquilo ali. Ele que sabe de sua necessidade, o dinheiro é dele. Se ele disser 'não, não aceito menos', o que se pode fazer? Ele trabalhou por aquilo ali, o direito é dele, não é verdade? Então a gente mostra os caminhos legais para que ele entre na justiça e receba aquilo dali. [...] Todo pequeno empreendedor tem o discurso padronizado de que a justiça do trabalho é paternalista. Ora, a justiça do trabalho às vezes sentencia o empregador a pagar em 12 vezes, a primeira parcela começando daqui a dois meses! Com um pai desse eu não preciso de inimigo! A nossa visão é deixar negociar para que não chegue até a justiça, para que o tra- 
balhador não chegue um elemento perdedor de seus direitos lá na frente. Por isso criou-se a CCP, e o princípio de que $60 \%$ é assegurado de imediato. [...] A gente chegou nesse número com um cálculo sobre o que o trabalhador ganha. Porque ele não pode receber indenização abaixo do salário que ele ganhava. O direito ou é aquilo ou é acima daquilo. A intenção é essa. [...] Na maioria das vezes fica nos 60\%. Hoje está consolidado isso daí, nenhuma empresa dá menos que isso" (entrevista realizada em julho de 2004).

Alguns pontos devem ser ressaltados nessa fala. Primeiro, que os trabalhadores são "instruídos a fazer acordos", isto é, resolver a questão na CCP e não na Justiça do Trabalho. É claro que, se algum trabalhador ainda quiser fazê-lo, estará em seu direito, mas as palavras empregadas pelo sindicalista não deixam dúvidas de que essa é uma solução não desejada pelo sindicato. O trabalhador estaria por sua conta e risco se decidisse recorrer à Justiça. Em segundo lugar, é evidente que empresas também têm preferido solucionar os conflitos relativos às indenizações rescisórias na CCP-CC e não na Justiça do Trabalho. Essa preferência deve estar relacionada, certamente, com a orientação do sindicato de que não pode haver acordo em que a indenização paga seja menor do que $60 \%$ do valor devido. O mais curioso é que o sindicalista apresenta esse valor como sendo de interesse do trabalhador, que, de outro modo, receberia menos na Justiça do Trabalho, ou talvez em condições que não lhe seriam vantajosas, como o mencionado parcelamento "em doze vezes". A Justiça do Trabalho é apresentada como um lugar onde o trabalhador perde os direitos, ou os recebe em condições desvantajosas.

De certo, isso representa um incentivo importante para que os empregadores não cumpram a legislação sobre despedida, pois sabem que sua "pena" será uma mesa de negociação em que agentes sem poder de execução de suas decisões aceitam por razoável uma conciliação na qual, se propõe pagar $60 \%$ do valor efetivamente devido. Está claro, pois, que o fato de o sindicato ter optado pelo acordo em lugar de penalizar as empresas que agem ilegalmente repercute no custo de não cumprir a lei. Não há incentivos ou injunções externas para que as empresas formalizem o contrato de seus trabalhadores. Se as há, provêm de fontes internas: a empresa principal que, por determinação de sua qualificação ISO ou outra qualquer, obriga as parceiras a agir conforme a lei. 


\section{CONCLUSÃO}

A inspeção do trabalho no Brasil segue os padrões definidos pela OIT em 1947. Suas instituições de apoio são, hoje, um pouco melhor aparelhadas do que há dez ou 15 anos, contando com um sistema informatizado de controle e produção de informação, melhor fluxo dos trâmites burocráticos e treinamento regular dos fiscais do trabalho. Possui um aparato nacionalmente implantado de investigação, com um total de 27 delegacias regionais do trabalho e pouco mais de 2 mil auditoresfiscais.

O desenho institucional parece, formalmente, adequado a uma inspeção efetiva, eficaz e eficiente do trabalho. Efetiva, porque parece atingir um número muito grande de trabalhadores como proporção da força de trabalho empregada. Eficaz pois resulta na melhoria das relações de trabalho e no saneamento de situações ilegais, como o nãorecolhimento do FGTS ou a não-assinatura da carteira de trabalho. E eficiente porque otimiza meios, se considerarmos que o sistema gasta em torno de um quarto dos recursos de investimento do MTE, sendo, em contrapartida, sua estrutura mais robusta e numerosa. Além disso, os procedimentos de controle da ação fiscal parecem também adequados para coibir fraudes e mitigar a corrupção. Do mesmo modo, a definição de prazos mais estritos para o trâmite processual administrativo das multas, por exemplo, que deve terminar em no máximo 60 dias, é de molde a inibir medidas protelatórias por parte das empresas, que necessitam de departamentos jurídicos bem-estabelecidos para enfrentar os trâmites judiciais posteriores aos trâmites administrativos. Isso incentiva a que pequenas e médias empresas fiscalizadas cumpram a lei. Em conseqüência, o sistema produz estatísticas bastante alentadas dos resultados da inspeção do trabalho.

Aqui começam os problemas. Em primeiro lugar, a se acreditar nessas estatísticas, a inspeção do trabalho atinge $80 \%$ ou mais do mercado de trabalho formal do país a cada ano, ou perto de $50 \%$ do mercado assalariado como um todo, isto é, incluindo trabalhadores com e sem carteira de trabalho. Contudo, vimos que uma proporção muito pequena dos potenciais destinatários é de fato beneficiada pela inspeção. Tudo indica que o sistema oferece incentivos seletivos para que os fiscais escolham empresas que, na verdade, não precisam ser fiscalizadas nesse aspecto específico - registro de vínculos empregatícios - porque já cumprem a lei. Com isso, a inspeção talvez reduza a propensão à ilegalida- 
de quanto a outros temas por parte dos empresários que são regularmente inspecionados, mas não parece capaz de atrair novos agentes para o sistema, agentes que atuam na estrita ilegalidade e que são, por isso mesmo, invisíveis nos registros do próprio MTE, quase todos construídos a partir de informações fornecidas pelas próprias empresas no âmbito da RAIS.

O segundo limite do sistema é a falta de recursos materiais, falta que os números portentosos da inspeção de fato escondem. Os pouco mais de 2 mil fiscais têm à sua disposição um universo anual de 2 a 3 milhões de empresas formalmente estabelecidas com pelo menos um empregado (uma vez mais segundo dados da RAIS), o que configura uma média de mil a 1.500 empresas potencialmente visitáveis por fiscal por ano, o que resulta em uma média de cinco a sete empresas por dia útil. O número de fiscais é, evidentemente, pequeno, principalmente porque aqui não estão computadas as empresas informalmente estabelecidas. Com isso, as DRTs estão condenadas a atender a denúncias que, ainda assim, não podem ser todas cobertas com o pessoal disponível. O sistema não está aparelhado para realizar uma de suas prerrogativas mais importantes, que é a visita de surpresa em empresas de qualquer tipo ou tamanho, estando na dependência da vontade ou interesse dos trabalhadores individuais ou seus representantes denunciar condições ilegais de trabalho.

Em termos do que interessa a este trabalho, isto é, as chances de um empresário ilegal ser apanhado e, sendo apanhado, sofrer sanções ou ser levado a sanar os problemas encontrados, há uma gradação entre dois pólos bem-marcados. No pólo da informalidade, isto é, em empresas de qualquer porte que não têm registro empresarial e não formalizam a relação de trabalho, as chances de que sejam fiscalizadas são muito remotas, estando exclusivamente na dependência de denúncias dos trabalhadores. A probabilidade dos trabalhadores denunciarem é inversamente proporcional ao seu medo do desemprego, sendo, portanto, tanto menor quanto maior a precarização do mercado de trabalho e as taxas de desemprego. Esse limite ficou claro na análise da construção civil do Rio de Janeiro. Nesse pólo, encontram-se, também, os trabalhadores por conta própria e os autônomos - profissionais liberais - que empregam, em geral, um ou outro agente administrativo. Em 2003 os assalariados sem carteira e os conta-própria - incluindo autônomos representavam 45,8\% da População Economicamente Ativa - PEA, se- 
gundo dados da PNAD. Esta é a parte da população que não será atingida pela fiscalização senão por puro azar.

No outro pólo, o da estrita formalidade, as chances de ser apanhado em caso de ilegalidade na relação de trabalho é diretamente proporcional ao tamanho das empresas. Pequenas empresas - até 20 empregados dificilmente serão fiscalizadas, porque o sistema oferece incentivos seletivos para que a fiscalização, forçada a escolher onde operar tendo em vista a insuficiência de pessoal, escolha as grandes empresas. Os dados e as entrevistas sugerem que o número "mágico" de empregados que coloca uma empresa na lista de possível inspecionada é 50. Assim, se uma empresa tem 50 ou mais empregados e apresenta alguma ilegalidade, sendo denunciada, a chance de que seja fiscalizada é muito alta.

Aqui entra o terceiro limite importante do sistema: a baixa taxa de regularização de vínculos empregatícios pode ser expressão da circunstância de que as grandes empresas têm possibilidades materiais para protelar a solução de qualquer irregularidade, muito além dos 60 dias legais dos processos administrativos. Recorrendo ao judiciário, os prazos ficam literalmente em suspenso, porque a justiça no Brasil é lenta e uma sentença pode levar anos. Por isso, os fiscais do trabalho entrevistados insistem em dizer que são as pequenas e médias empresas que pagam multas ou regularizam as relações de trabalho quando fiscalizadas. O custo, para elas, de protelar uma solução via ação judicial pode ser alto demais. Isso pode estar explicando o fato de que $21 \%$ das empresas autuadas resultaram em apenas $1,17 \%$ de situações de trabalho regularizadas. As grandes empresas ou são de fato mais "legais", ou conseguem elidir as obrigações contratuais via recursos judiciais.

Entre esses dois pólos, encontra-se a maioria das empresas, embora não a maior proporção de trabalhadores empregados. Essas dificilmente serão fiscalizadas. São empresas formais, com número significativo de trabalhadores, mas que, mesmo sendo denunciadas, se aproveitam das lacunas do sistema de inspeção para empurrar até a prescrição as ações que têm contra si. Cabe registro de depoimento de auditorfiscal no sentido de que há ingerência política na nomeação dos delegados regionais do trabalho; e são estes que aplicam as multas. Em qualquer caso, porém, a chance de uma empresa ser inspecionada é diretamente proporcional à propensão dos trabalhadores denunciarem as irregularidades. 
É verdade que, nos últimos anos, o governo federal vem promovendo campanhas de esclarecimento da população e oferecendo telefones para denúncias anônimas. No entanto, a eficácia desses instrumentos pode ser comprovada não tanto na repressão da rotineira sonegação de direitos trabalhistas, mas sim em situações mais dramáticas, como "redução à condição análoga à de escravo" e a exploração do trabalho infantil. Recentemente, três fiscais do trabalho foram assassinados em Minas Gerais no exercício de suas funções, aparentemente a mando de um fazendeiro ligado a um importante político da região e que mantinha trabalhadores em regime de trabalho forçado em suas fazendas. Denúncias espocaram no Pará, Bahia, Pernambuco, Rio Grande do Sul, São Paulo e outros estados, e o trabalho escravo - principalmente escravização por dívidas - parece estar sendo eficazmente combatido. $\mathrm{O}$ mesmo pode ser dito a respeito do trabalho infantil, que vem sendo enfrentado não apenas com a fiscalização, mas também com as políticas públicas de renda mínima, quase todas atreladas à atenção das crianças à escola.

Do ponto de vista do que interessa a este trabalho, a inspeção do trabalho parece direcionada para as empresas com menor potencial de ilegalidade, resultando em alta efetividade (grande número de trabalhadores atingidos pela fiscalização) mas baixíssima eficácia relativa (vínculos regularizados na ação fiscal). Ainda assim, o sistema de multas e o processo de sua cobrança mostraram-se coercitivos o suficiente para forçar as empresas menores a regularizar sua situação e também pagar as multas. Como sempre, porém, as grandes empresas contam com a ineficiência do sistema judiciário para elidir o cumprimento das leis.

(Recebido para publicação em fevereiro de 2005) (Versão definitiva em setembro de 2005) 


\section{NOTAS}

1. Uma boa revisão crítica da literatura sobre os efeitos da legislação trabalhista nos mercados de trabalho dos países da Organização para a Cooperação e o Desenvolvimento Econômico - OCDE pode ser encontrada em Bertola, Boeri e Cazes (1999), em que se argumenta que a evidência disponível não é suficiente para sustentar a idéia de que mercados de trabalho mais flexíveis são mais eficientes ou mais equitativos. Squire e Suthiwart-Narueput (1997) analisam dados de diversos países do Terceiro Mundo para concluir na mesma direção. Um bom estudo sobre os efeitos (nulos) da Constituição de 1988 sobre a dinâmica do mercado de trabalho no Brasil é Barros et alii (1999). Argumentos no sentido contrário podem ser encontrados em Marques e Pagés (1998), Scarpetta (1998) e Heckman e Pagés (2000).

2. Dentre os resultados não almejados está a crescente precariedade do trabalho e suas conseqüências na integração social, as diferenças nos salários segundo a idade, o gênero ou o grupo étnico, a subsistência de grupos altamente vulneráveis ao desemprego, como os jovens, ou o aumento da pobreza entre os assalariados, todos amplamente documentados em diversas pesquisas, como Cardoso (2000); Cardoso Jr. (2000); Tockman e Martínez (1999); Egger (1999a; 1999b); Berry e Mendez (1999); Guimarães (2002), Cardoso (2003), dentre outras.

3. Exceção a essa regra é Squire e Suthiwart-Narueput (1997). É longa, no Brasil, a discussão em torno da efetividade da lei no cotidiano das relações de trabalho, embora não da perspectiva mencionada, isto é, a eficiência dos mercados de trabalho. Um ótimo apanhado da discussão sobre a efetividade ou não da Consolidação das Leis do Trabalho ao longo da história é French (2001:16-23; 35-45).

4. Até o momento da redação deste artigo, a Convenção 81 fora ratificada por 133 países, a Armênia tendo sido o último país a fazê-lo, em dezembro de 2004.

5. São exemplos de verbas incontroversas: o salário, o 13ํㅡ, as férias, o FGTS, quando admitido o vínculo de emprego; são exemplos de verbas controversas: os adicionais de hora extra, de periculosidade, de insalubridade, de isonomias salariais e outros casos em que a demanda trabalhista requer que o trabalhador proveja suas alegações.

6. No Código Penal estão tipificados os "crimes contra a organização do trabalho" arts. 197 a 203 - de pouco interesse para este estudo, na medida que a "Parte Especial do Código Penal é espelho fiel do Código Rocco italiano, código sabidamente de inspiração fascista", no entender de Nogueira (2000).

7. É certo que o contrário é bastante comum, na verdade típico em algumas cadeias de produção, como a química (Mello e Silva e Rizek, 1997), a têxtil (Costa, 2002); a de construção civil e a de produtos de linha branca, como fogões e geladeiras (Gitahy, 1997). Na indústria automobilística, em razão de acidentes graves decorrentes de falhas de controle de qualidade nas empresas terceirizadas, a transferência de padrões tecnológicos e de qualidade vem melhorando as relações de trabalho nas franjas da cadeia produtiva (Carvalho, 2001; Marx, Salerno e Zilbovicius, 2003), sem contudo ser suficiente para obrigar as terceiras à adequação à lei.

8. Ver, dentre outros, Werneck Vianna (1999); Tavares de Almeida (1978); Gomes (1988); Rodrigues (1977); Moraes Filho (1979); e French (2001).

9. São extensas, ao longo da história, as denúncias de ineficiência do sistema de fiscalização. Número pequeno de fiscais do trabalho, corrupção dos fiscais existentes, 
DRTs desaparelhadas, inflação corroendo o valor das multas, esses são apenas alguns aspectos apontados na análise de French (2001) e que, segundo alguns, persistem até hoje (p. ex., Cappellin, 2005).

10. Até então a atividade era regulada unicamente pela CLT e por instruções normativas e decretos do Ministério do Trabalho e Previdência Social - MTPS.

11. Os dados da tabela referem-se ao orçamento efetivamente executado em cada ano, deflacionado pela inflação acumulada média do ano, deflator construído com base no Índice Nacional de Preços ao Consumidor. Para 2003, a execução estava fechada até setembro no momento quando os dados foram coligidos a partir do endereço eletrônico da Câmara dos Deputados.

12. O aumento da participação do MTE no OGU foi algo artificial em 2003, em razão da Lei Complementar no 110, de 2001, que obrigou o Estado a ressarcir os titulares de contas do FGTS das perdas de planos econômicos passados. Esses recursos (R \$1.7 bilhão) saíram do FAT.

13. O orçamento da União, de onde foram extraídos esses dados, pode ser encontrado no seguinte endereço eletrônico: http://www.camara.gov.br/internet/orcament/principal.

14. Decreto no 4.552/02 - Art. 3우 "Os auditores-fiscais do trabalho são subordinados tecnicamente à autoridade nacional competente em matéria de inspeção do trabalho."

15. CLT - Decreto-lei no 5452/43: Art. 161: “O Delegado Regional do Trabalho, à vista de laudo técnico do serviço competente que demonstre grave e iminente risco para o trabalhador, poderá interditar estabelecimento, setor de serviço, máquina ou equipamento, ou embargar obra, indicando na decisão, tomada com a brevidade que a ocorrência exigir, as providências que deverão ser adotadas para prevenção de infortúnios do trabalho."

16. A competência do auditor-fiscal, quando o empregador faz parte da administração pública - a União, os Estados, os Municípios, autarquias, e fundações públicas - se dá quando há empregados, ou seja, quando há contrato de trabalho regido pela mesma legislação que rege o trabalho subordinado nos contratos privados. As empresas de economia mista e as empresas públicas têm regime de contratação trabalhista privado e, portanto, estão sujeitas à fiscalização.

17. RIT - Decreto n⿳ $4.552 / 02$ - Art. 4: "Para fins de inspeção o território de cada unidade federativa será dividido em circunscrições, e fixadas as correspondentes sedes." As Delegacias Regionais do Trabalho, uma em cada Estado da Federação, coincidem com as circunscrições de que fala este artigo.

18. Essa atividade de aplicar multas é ato vinculado, isto é, o delegado tem poder/dever de aplicar as multas e não tem autonomia para impedir o curso do processo administrativo automaticamente instalado pelo protocolo do auto de infração. No entanto, o Ministro do Trabalho tem poder de "avocar" o processo, ou seja, retirá-lo das instâncias administrativas inferiores, para exame e decisão.

19. Dados em MTE (2004:5), em dólares de julho de 2004.

20. Conforme pode-se ler em documento do próprio MTE (2004:7), “La mayor fuente de informaciones que, obedecidas las prioridades definidas en el planeamiento, orientará la acción fiscal son las denuncias oriundas de entidades sindicales de trabajadores, Ministerio Público del Trabajo, otras entidades gubernamentales y no guberna- 


\section{Adalberto Cardoso e Telma Lage}

mentales y de los propios trabajadores que buscan diariamente la Guardia Fiscal de las DRT".

21. Para esta seção, levamos em conta entrevistas com seis auditores-fiscais do Rio de Janeiro, um de São Carlos, interior de São Paulo, além de um subdelegado em cada estado.

22. Todas essas informações estão em Bensusán (2005).

23. Essa suspeita é sustentada fortemente por uma entrevistada, que disse, textualmente: "É preciso esclarecer que o Ministério do Trabalho não fiscaliza o mercado informal de trabalho. Sabemos que as ruas estão cheias de trabalhadores informais, mas isso é ignorado pela ação fiscal. Fiscalizamos empresas, ou seja, organizações em que é possível identificar um empregador e seus subordinados".

24. Em 1994, segundo dados da RAIS-MTE, havia 23 milhões de assalariados com carteira no país, mesmo número de trabalhadores atingidos pela fiscalização, que teria, assim, coberto $100 \%$ do mercado formal.

25. A construção civil ocupava 3,8\% dos empregados com carteira no país em 2000, segundo a RAIS, mas era responsável por 7,4\% dos acidentes de trabalho formalmente registrados no MTE. Dados disponíveis no site www.mte.gov.br.

26. Formados pontualmente para cada obra em particular (porque cada obra será realizada por um condomínio sempre diferente de empresas), os condomínios se estão generalizando na construção civil. Trata-se de pessoas jurídicas com Cadastro Específico do Instituto Nacional de Seguridade Social, cadastro administrado pelo INSS e que contempla empregadores desobrigados de inscrição no Cadastro Nacional de Pessoas Jurídicas - CNPJ, mas que são contribuintes obrigatórios da Previdência Social, como por exemplo condomínios, empregadores domésticos, empregadores eventuais (construção, reformas). Ao final de cada obra (um prédio, por exemplo), a pessoa jurídica responsável por ela, ou seja, o condomínio, deixa de existir.

27. Os dois sindicatos fizeram questão de marcar a queda no número de óbitos por acidente de trabalho na construção civil em 2003 (três óbitos), comparando com o ano de posse da nova diretoria do sindicato laboral (17 óbitos).

28. Estimativa baseada no Censo de 2000 e projetada com base nas informações da PNAD-2002 para a Região Metropolitana do Rio de Janeiro.

29. Pesquisa bibliográfica realizada por Mendes (2003) levantando todas as teses e dissertações sobre saúde e trabalho no Brasil desde 1950 encontrou apenas uma dissertação de mestrado sobre construção civil no Rio de Janeiro, ainda assim para o ano de 1987. O tema não é estudado pela academia brasileira, apesar de a construção civil apresentar o maior índice de acidentes de trabalho no país desde sempre.

30. Wunsch Filho (1999) argumenta que a reestruturação produtiva vem contribuindo para a queda no número de acidentes de trabalho na indústria brasileira. Cremos, porém, que a causa mais importante é a maior informalização das relações de trabalho, que reduz o número de trabalhadores cobertos pela previdência e, com isso, a informação oficial sobre acidentes efetivamente ocorridos. 


\section{REFERÊNCIAS BIBLIOGRÁFICAS}

BARROS, R. P., CORSEUIL, C. H. e GONZAGA, G. (1999), “Labor Market Regulations and the Demand for Labor in Brazil". Texto para Discussão, n⿳0 398, Departamento de Economia, PUC-Rio.

BELOT, M. e OURS, J. C. (2001), “Unemployment and Labor Market Institutions: An Empirical Analysis". Journal of Japanese and International Economics, no 15, pp. 403-418.

(2004), "Does the Recent Success of some OECD Countries in Lowering their Unemployment Rates Lie in the Clever Design of their Labor Market Reforms?". Oxford Economic Papers, no 56, pp. 621-642.

BENSUSÁN, G. (2005), La Inspección del Trabajo en México: Diseño Legal y Desempeño Real. Trabalho apresentado no seminário Labor Inspection and Labor Markets, MIT, janeiro.

BERRY, A. e MENDEZ, M. T. (1999), "Policies to Promote Adequate Employment in Latin America and the Caribbean (LAC)". Employment and Training Paper, no 46, OIT, Genebra, Suíça.

BERTOLA, G., BOERI, T. e CAZES, S. (1999), “Employment Protection and Labour Market Adjustment in OECD Countries: Evolving Institutions and Variable Enforcement". Employment and Training Papers, no ${ }^{2}$. Geneva, ILO.

CAPPELliN, P. (coord.). (2005), A Experiência dos Núcleos de Promoção da Igualdade de Oportunidades e Combate à Discriminação no Emprego e na Ocupação. Brasília, OIT.

CARDOSO, A. M. (2000), Trabalhar, Verbo Transitivo: Destinos Profissionais dos Deserdados da Indústria Automobilística. Rio de Janeiro, Fundação Getulio Vargas Editora.

(2003), A Década Neoliberal e a Crise dos Sindicatos no Brasil. São Paulo, Boitempo.

CARDOSO JR., J. C. (2000), Desestruturação do Mercado de Trabalho Brasileiro e Limites do seu Sistema Público de Emprego. Palestra proferida no $3^{\text {o }}$ Congresso Latino-Americano de Sociologia do Trabalho. Buenos Aires.

CARVALHO, R. Q. (2001), Relações Interfirmas, Governança e Desenvolvimento Tecnológico na Cadeia Automotiva Brasileira. Trabalho apresentado no seminário A Indústria Automobilística nas Américas. Rio de Janeiro. Manuscrito.

COSTA, M. S. (2002), Despotismo de Mercado: Medo do Desemprego e Relações de Trabalho em Contexto de Reestruturação Produtiva Brasileira dos Anos 90. Tese de Doutorado. Rio de Janeiro, IUPERJ.

DAL ROSSO, S. (1997), A Jornada de Trabalho na Sociedade. Brasília, UnB.

DINIZ, E. e BOSCHI, R. (1976), Empresariado Nacional e Estado no Brasil. Relatório de Pesquisa. Rio de Janeiro, IUPERJ, 2 vols.

EGGER, P. (1999a), “El Desempleo de los Jóvenes en los Países Andinos (Colombia, Ecuador, Perú y Venezuela) Situación y Perspectivas". Documento de Trabajo, no 103. OIT, Equipo Técnico para Países Andinos, Lima, Peru. 
(1999b), “El Mercado Laboral en los Países Andinos: Un Compendio de Datos so-

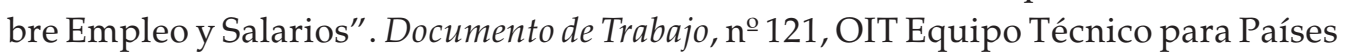
Andinos, Lima, Peru.

FRENCH, J. D. (2001), Afogados em Leis. A CLT e a Cultura Política dos Trabalhadores Brasileiros. São Paulo, Editora Fundação Perseu Abramo.

GOMES, A. de C. (1988), A Invenção do Trabalhismo. Rio de Janeiro/São Paulo, IUPERJ/Vértice.

GITAHY, L. (1997), “Reconfigurando as Redes Institucionais: Relações Interfirmas, Trabalho e Educação na Indústria de Linha Branca". Educação \& Sociedade, vol. 18, nº 61, pp. 228-253.

GUIMARÃES, N. A. (2002), Caminhos Cruzados: Estratégias de Empresas e Trajetórias de Trabalhadores. Tese de Livre-Docência, USP, São Paulo.

HECKMAN, J. e PAGÉS, C. (2000), “The Cost of Job Security Regulation: Evidence from Latin American Labor Markets". Working Paper, no 430, Inter-American Development Bank.

LEMOS, A. H. C. (2003), Qualificação Profissional e Desemprego: A Construção Social de um Problema. Tese de Doutorado em Sociologia, IUPERJ, Rio de Janeiro.

LOBO, V. M. (2005), Os Trabalhadores e a Política Social no Brasil. Tese de Doutorado, IUPERJ (em preparação).

MARQUES, G. e PAGÉS, C. (1998), Ties that Bind: Employment Protection and Labor Market Outcomes in Latin América. Inter-American Development Bank. Manuscrito.

MARX, R., SALERNO, M. S. e ZILBOVICIUS, M. (2003), The Automobile Industry in Brazil: Production Strategies and Best Practices in Supply Chain Management. Trabalho apresentado na EUROMA - POMS Joint International Conference, Como. One World? One View of OM? The Challenges of Integrated Research and Practices. Manuscrito.

MELLO E SILVA, L. e RIZEK, C. S. (1997), “Algumas Observações sobre a Qualificação do Trabalho no Complexo Químico Paulista". Anais do XXI Congresso da ALAS, São Paulo, pp. 57-58.

MENDES, René. (2003), “Produção Científica Brasileira sobre Saúde e Trabalho, Publicada na Forma de Dissertações de Mestrado e Teses de Doutorado, 1950-2002". Revista Brasileira de Medicina do Trabalho, http://www.anamt.org.br/downloads/revista02.zip.

MINISTÉRIO DO TRABALHO E EMPREGO - MTE. (2004), Inspeción del Trabajo en Brasil. Brasília, MTE. Manuscrito.

MORAES FILHO, E. (1979) [1952], O Problema do Sindicato Único no Brasil. São Paulo, Alfa-Ômega.

NOGUEIRA, M. de A. (2000), "Os Crimes contra a Organização do Trabalho", in G. A. Vogel Neto (org.), Curso de Direito do Trabalho. Rio de Janeiro, Forense.

OLIVEIRA, F. de. (1972), “A Economia Brasileira: Crítica da Razão Dualista”. Novos Estudos Cebrap, no 2 . 
PALOMINO, H. e SENÉN, C. (2005), La Inspección del Trabajo en Argentina. Trabalho apresentado no seminário Labor Inspection and Labor Markets, MIT, janeiro.

RODRIGUES, J. A. (1977), Sindicatos e Desenvolvimento. São Paulo, Símbolo.

SCARPETTA, S. (1998), "Labour Market Reforms and Unemployment. Lessons from the Experience of the OECD Countries". Working Paper, no 382, Inter-American Development Bank, Office of the Chief Economist.

SILVA, M. R. (2002), Inspeção do Trabalho. Procedimentos Fiscais. Goiânia, AB.

SQUIRE, L. e SUTHIWART-NARUEPUT, S. (1997), “The Impact of Labor Market Regulations". The World Bank Economic Review, vol. 11, no 1, pp. 119-143.

TAVARES DE ALMEIDA, M. H. (1978), Estado e Classes Trabalhadoras no Brasil (1930-1945). Tese de Doutorado em Ciência Política, FFLCH-USP, São Paulo, 2 vols.

TOCKMAN, V. e MARTÍNEZ, D. (1999), “La Agenda Laboral en la Globalización: Eficiencia Económica con Progreso Social". Documento de Trabajo, nº 94, OIT Oficina Regional para América Latina y el Caribe, Lima, Perú.

WERNECK VIANNA, L. J. (1999), Liberalismo e Sindicato no Brasil (4ํㅡㄹ ed. revista). Belo Horizonte, UFMG.

WUNSCH FILHO, Victor. (1999), "Reestruturação Produtiva e Acidentes de Trabalho no Brasil: Estrutura e Tendências". Caderno de Saúde Pública, vol. 15, no 1. 


\section{ABSTRACT \\ Labor Inspection in Brazil}

One aspect the literature overlooks on the effects of labor regulation of labor market efficiency is the degree of the legislation's effectiveness, i.e., its actual enforcement in daily work relations. Even the more sophisticated econometric studies (which take into account the effects of interaction between labor market regulatory institutions in explaining its dynamics) leave this central issue aside, namely enforcement versus non-enforcement of the law. Keeping this issue in mind, we seek to answer the following question in this article: given that the effectiveness of labor legislation depends on the interaction between the overall sanctions and the probability of the employer getting caught breaking the law, and given that the law's effectiveness is a decisive aspect for the real measurement of a country's labor costs, to what extent is the Brazilian labor inspection system designed to meet its objective, namely to enforce the law?

Key words: labor legislation; labor inspection; construction industry

\section{RÉSUMÉ}

\section{L'Inspection du Travail au Brésil}

L'un des aspects négligés dans la littérature concernant les effets de la régulation du travail sur l'efficacité des marchés du travail est le degré d'action réelle de la loi, c'est-à-dire sa vraie portée dans les relations du travail de chaque jour. Des études économétriques pourtant relativement élaborées, qui tiennent compte des effets d'interaction entre institutions régulatrices du marché du travail dans l'explication de leur fonctionnement, ignorent la question centrale qui est l'obéissance ou non à la loi. Dans cet article on se pose la question: puisque la force de la législation du travail découle de l'effet d'interaction entre le montant des sanctions et les chances qu'a l'employeur d'être pris en faute; et puisque l'action effective de la loi est un aspect décisif pour une exacte mesure des coûts du travail d'un pays, dans quelle mesure le système d'inspection du travail au Brésil est pensé pour atteindre son objectif, qui est celui de faire respecter la loi?

Mots-clé: législation du travail; inspection du travail; travaux publics 